\title{
Refratários contendo carbono: propriedades, características e variáveis em sua composição
}

\section{(Carbon containing refractories: properties, characteristics and variables in their composition)}

\author{
C. S. Bitencourt, V. C. Pandolfelli \\ Departamento de Engenharia de Materiais, Universidade Federal de S. Carlos, \\ Rod. Washington Luiz, km 235, C. P. 676, S. Carlos, SP 13565-905 \\ celinasb@gmail.com,vicpando@power.ufscar.br
}

\begin{abstract}
Resumo
Por seu singular conjunto de propriedades e características, os refratários contendo carbono têm sido fundamentais para que a indústria siderúrgica alcance seus atuais níveis de produtividade. Apesar disso, investir no desenvolvimento desses materiais continua a ser necessário, sobretudo devido à crescente pressão para que o setor siderúrgico torne seus processos mais seguros e sustentáveis, objetivos esses que dependem diretamente do desempenho dos refratários utilizados ao longo da cadeia produtiva do ferro e do aço. Assim, com o intuito de indicar oportunidades de desenvolvimento ainda não exploradas, bem como de examinar as linhas de pesquisa que têm obtido êxito em aumentar a eficiência dos refratários contendo carbono, este trabalho faz uma ampla revisão dos possíveis constituintes destes materiais, tais como ligantes, fontes de carbono e aditivos diversos. Das inovações recentemente divulgadas, analisa-se o uso de adições combinadas de agentes antioxidantes e $\mathrm{TiO}_{2}$ para promover o desenvolvimento de fases com morfologias especiais (como whiskers), e a descoberta de aditivos que possibilitam a grafitização do carbono produzido pelas resinas termofixas. Este último avanço é particularmente significativo, pois proporciona às resinas uma capacidade antes exclusiva do piche de alcatrão, ligante que vem sendo evitado pelas condições insalubres que causa tanto no ambiente da indústria siderúrgica como refratarista. Já entre as possibilidades de inovação cogitadas, destaca-se a adição de agentes de acoplagem aos refratários resinados com o objetivo de otimizar, sobretudo, a sua processabilidade. Tal avanço seria especialmente desejável para os concretos refratários resinados, materiais que atualmente possuem aplicações limitadas, mas que atraem grande interesse por suas diversas vantagens em relação aos produtos pré-conformados, o que os leva a ser um importante foco para novos desenvolvimentos.
\end{abstract}

Palavras-chave: refratários contendo carbono, resinas fenólicas, whiskers, agentes de acoplagem.

\begin{abstract}
Due to their unique set of properties and characteristics, carbon containing refractories have been a key issue in order that the steelmaking industry could attain its current productivity levels. However, further development of these materials is still necessary, especially due to the increasing pressure on the steelmaking sector to make its processes safer and more sustainable, goals which directly depend on the performance of the refractories used for the iron and steel production chain. Thus, in order to identify opportunities not yet explored, as well as to examine the research lines that have been successful in increasing the carbon containing refractory performance, this paper presents an extensive review regarding likely components of these materials, such as binders, carbon sources and additives. Based on the innovations recently disclosed, it is pointed out the use of combined additions of antioxidants agents and $\mathrm{TiO}_{2}$ to promote the development of phases with special morphologies (such as whiskers), and novel additives that enable the graphitization of the carbon from the thermosetting resins. This latter advance is particularly significant, because it provides to the resins a capacity before exclusive of the coal tar pitch, binder which has been avoided due to the unhealthy conditions that it brings to the steelmaking industry workplaces, as well as to the refractories industry. Among the possibilities of innovation pointed out, it is highlighted the addition of coupling agents to the resin bonded refractories in order to optimize its processability. Such improvement would be particularly important for resin bonded castables, materials that currently have limited applications, but are attracting great interest due to their many advantages over preformed products, which make them an important target for new developments.
\end{abstract}

Keywords: carbon bonded refractories, phenolic resins, whiskers, coupling agents.

\section{INTRODUÇÃO}

Sendo responsável pelo consumo de mais de $60 \%$ da produção mundial de refratários [1], a indústria do aço não poderia deixar de ser uma das partes mais interessadas pelo desenvolvimento dessa classe de materiais tão essencial aos seus processos. No entanto, as justificativas para tal interesse já há tempos não residem mais apenas nos benefícios quanto à redução de custos, aumento da produtividade e ganho na qualidade do produto final: a busca por um ambiente de 
trabalho salubre e pela minimização dos impactos ambientais são atualmente metas tão ou até mais importantes, visto que tais condições estão se tornando exigências legais para permitir o funcionamento de qualquer unidade fabril, o que inclusive abrange os próprios fabricantes de cerâmicas refratárias.

Considerando esta situação e a perspectiva de que tais legislações se enrijeçam cada vez mais, passa a ser vantajoso tanto às siderúrgicas quanto à indústria de refratários sempre se adiantar a elas, o que torna ainda mais valioso o estabelecimento de um estímulo mútuo entre esses dois setores para o desenvolvimento de cerâmicas refratárias que apresentem as seguintes características: que possam ser processadas e aplicadas utilizando o mínimo de insumos possível, com destaque para os insumos energéticos; que apresentem um ciclo de vida prolongado, reduzindo assim a geração de resíduos e o gasto de insumos para a troca e/ou reforma dos revestimentos; e que contenham e/ou produzam quantidades mínimas de substâncias poluentes e/ou potencialmente tóxicas, reduzindo os riscos relativos à sua produção, uso e disposição final. $\mathrm{Na}$ busca pelos dois primeiros objetivos citados, destaca-se o crescente desenvolvimento e interesse pelo uso de refratários monolíticos em lugar dos produtos pré-conformados, como os tijolos prensados convencionais [2,3]. Já o terceiro objetivo tem um caráter decisivo, pois está relacionado diretamente à composição química do material, a qual muitas vezes é responsável por definir suas propriedades mais intrínsecas. Ou seja, alterações profundas podem acabar sendo necessárias para satisfazer os requisitos quanto à salubridade, que é o que está ocorrendo no caso dos refratários contendo óxidos de cromo, que vêm sendo substituídos devido ao risco de liberação do íon $\mathrm{Cr}^{6+}$, um já comprovado agente cancerígeno $[1,4]$.

Muito valorizadas por suas propriedades únicas, como elevadaresistênciaaochoquetérmicoereduzidamolhabilidade pelas escórias siderúrgicas, a classe dos refratários contendo carbono também tem precisado passar por importantes transformações para conseguir se desenvolver rumo a essas novas metas de sustentabilidade. Dentre todas, uma das mais importantes advém da necessidade de encontrar fontes de carbono capazes de substituir de forma satisfatória o piche de alcatrão na função de ligante da composição refratária. Essencialmente, isso significa encontrar um substituto que não apresente os problemas do piche quanto à liberação de voláteis nocivos, mas que possa manter a sua qualidade de produzir um carbono grafitizável (uma vez que, como será visto a seguir, a estrutura anisotrópica que este carbono desenvolve proporciona aos refratários resistência química e propriedades termomecânicas superiores).

Considerando a emissão de voláteis, os substitutos mais promissores para o piche seriam as resinas termofixas da classe das fenólicas, as quais também são vantajosas por permitirem que o refratário mantenha uma maior resistência mecânica ao longo do processo de queima (já que elas se tornam infusíveis após suas reações de cura, enquanto o piche permanece fusível). Tal capacidade também seria favorável à produção de refratários monolíticos contendo carbono, um potencial que já tem se transformado em realidade, isso apesar dos obstáculos assinalados na literatura $[3,5,6]$. Contudo, nessa substituição do piche pelos polímeros termofixos são diversas as variáveis que devem ser consideradas, como a escolha da própria resina (em vista da vastidão da classe das resinas fenólicas), do seu agente de cura, solventes e de possíveis aditivos secundários. Entre estes últimos, estariam inclusos justamente os aditivos que teriam o papel de favorecer a grafitização do carbono obtido com a pirólise do termofixo, uma vez que estes materiais costumam gerar apenas um carbono não grafitizável, mesmo quando tratados a temperaturas superiores a $2000{ }^{\circ} \mathrm{C}$. Simultaneamente à substituição do ligante, é oportuno que todos os demais elementos da composição refratária sejam novamente selecionados, de modo a favorecer que o conjunto final seja o mais compatível possível e, portanto, capaz de atingir seu máximo desempenho. Assim, com o intuito de propiciar as bases para repensar a formulação dos refratários contendo carbono no sistema $\mathrm{MgO}-\mathrm{C}$, este artigo procura apresentar e discutir as vantagens e desvantagens das suas possíveis matérias-primas e aditivos. Para facilitar comparações, estes componentes, de acordo com suas funções e características, foram distinguidos entre fontes de carbono particuladas, ligantes (entre os quais estão as próprias resinas fenólicas), aditivos antioxidantes, aditivos para o desenvolvimento de fases especiais e agentes de acoplagem. Estando o foco nas fases do refratário compostas por carbono, o estudo aqui desenvolvido não incluiu uma análise das fontes de $\mathrm{MgO}$.

Com base nas informações e discussões levantadas, serão definidas as rotas de pesquisa julgadas como as mais promissoras para o desenvolvimento dos refratários contendo carbono. Isso significa, sobretudo, rotas que possibilitem tirar o máximo proveito dos aspectos positivos do uso das resinas fenólicas como ligantes, que possam elevar o desempenho desses refratários de modo geral, e que favoreçam sua evolução como produtos monolíticos.

\section{O CARBONO E SUAS FONTES PARA O REFRATÁRIO}

Das cinco formas alotrópicas atualmente conhecidas para o elemento carbono, a estrutura de lâminas hexagonais empilhadas que caracteriza o grafite é a mais desejável para participar da constituição dos materiais refratários. Muito além da sua elevada resistência à temperatura (começaria a sublimar a partir de $\approx 3700{ }^{\circ} \mathrm{C}$, sendo fusível apenas sob altas pressões [7]), o grafite apresenta outras importantes características e propriedades que permitem a ele beneficiar o desempenho desses materiais em diversos aspectos: um baixo coeficiente de expansão térmica que, combinado com sua elevada condutividade térmica e com a flexibilidade de sua estrutura cristalina, pode proporcionar ao refratário uma grande resistência às solicitações de choque térmico [8-10]; a maior condutividade térmica que ele confere ao refratário também pode levar à formação de uma camada de metal viscosa, ou até mesmo solidificada, sobre a face quente do revestimento, o que o protegeria da degradação 
[11]; suas boas propriedades mecânicas tanto a baixas como a altas temperaturas [9]; a compressibilidade de sua estrutura na direção perpendicular aos planos de grafenos, o que permite que ele absorva a expansão de outros materiais ao seu redor, como a dos agregados de óxidos presentes na composição do refratário $[8,9]$; e sua reduzida energia superficial, que o torna não-molhável por uma grande variedade de líquidos, no que se incluem os óxidos fundidos que compõem as escórias siderúrgicas e a maioria dos metais não-ferrosos e suas ligas. Essa baixa molhabilidade confere ao refratário uma maior resistência química ao ataque desses agentes, mesmo a temperaturas elevadas [8,9]. Todas essas propriedades decaem significativamente à medida que se vai do grafite monocristalino ao carbono em estado amorfo, um comportamento que também é observado para a principal limitação desses materiais, que é sua resistência à oxidação. Em temperaturas acima de $400{ }^{\circ} \mathrm{C}$, o grafite já se torna susceptível à reação com oxigênio, $\mathrm{CO}_{2}$ e demais gases oxidantes $[7,9,12]$, uma reatividade que aumenta com a imperfeição da estrutura grafítica devido ao crescimento da área superficial interna $[9,13]$ e também da densidade de sítios reativos.

Como já observado acima, uma segunda limitação do carbono grafítico para a sua aplicação em siderurgia está no fato de que justamente entre os poucos metais capazes de molhá-lo se encontram o ferro e suas ligas (especialmente as com baixo teor de carbono). Isso os torna então aptos para dissolver o carbono do refratário, o que contribuiria para a corrosão do revestimento [14]. Nessas circunstâncias, a combinação do carbono com óxidos refratários estáveis como o $\mathrm{MgO}$ demonstra suas grandes vantagens, pois esses óxidos, além de indiferentes ao oxigênio, costumam ser pouco molháveis pelo ferro líquido [15], o que então os torna mais resistentes ao ataque químico das ligas ferrosas. Por outro lado, os óxidos refratários não apresentam essa mesma capacidade em relação às escórias siderúrgicas. Com isso, acaba surgindo um sistema de proteção mútua, com o carbono protegendo o óxido da escória, enquanto o óxido o protege do metal e do oxigênio $[8,9]$. Portanto, percebese que as formas de adição do carbono à composição do refratário devem ser sempre muito bem analisadas, uma vez que afetam não apenas o processamento, mas também as propriedades finais do material. Desse modo, nas seções seguintes, procurar-se-á avaliar como as principais fontes de carbono usadas atualmente interferem nesses dois aspectos igualmente importantes para o desenvolvimento dos refratários. Primeiramente, será discutida a característica da grafitizabilidade dessas matérias-primas, as quais depois serão analisadas uma a uma, distinguindo-as entre fontes de carbono particuladas e fontes que também atuam como ligantes.

\subsection{Grafitizabilidade}

Entre o carbono completamente amorfo e o cristal de grafite, parece ser possível atingir qualquer nível de organização cristalográfica apenas pela escolha da fonte de carbono e da suas condições de tratamento (temperatura, pressão, atmosfera, etc.), proporcionando uma diversidade que não é tão convencional para outras substâncias refratárias [16]. Essas estruturas intermediárias entre o carbono amorfo e o cristalino são denominadas como não grafíticas, não podendo ser definidas como amorfas por já apresentarem alguma organização de curto alcance. Considerando a questão da capacidade das fontes de carbono para se cristalizarem como grafite, torna-se possível classificálas em dois grandes grupos, o das fontes grafitizáveis e o das não grafitizáveis. No caso das primeiras, o processo de carbonização leva à formação de um carbono não cristalino, mas que pode ser grafitizado se submetido a temperaturas acima dos $2200{ }^{\circ} \mathrm{C}$ [17], sendo este o caso de algumas variedades do piche de alcatrão e do piche de petróleo. Já no grupo das fontes não grafitizáveis, no qual se encontram os polímeros termofixos, o carbono não grafítico formado na carbonização não é capaz de se grafitizar mesmo quando tratado a temperaturas da ordem de $3000{ }^{\circ} \mathrm{C}$. Em artigo de 2005, Harris [13] faz uma interessante abordagem sobre as teorias desenvolvidas até o momento que procuram explicar os motivos da existência dessas duas variedades de fontes de carbono, incluindo uma teoria mais recente, baseada na estrutura dos fulerenos.

Pelas informações comentadas acima, já é possível concluir que, sendo compostos pelo piche ou pelo polímero termofixo, não se poderia esperar que ocorresse de maneira espontânea a formação do grafite nos refratários contendo carbono aplicados à siderurgia, visto que estes costumam ser produzidos e utilizados em temperaturas inferiores a $2000{ }^{\circ} \mathrm{C}$. Ou seja, carbonos com estrutura não grafítica permaneceriam em ambos os casos. Porém, como o nível de organização cristalográfico dessa estrutura pode ser muito diverso, as propriedades dos carbonos produzidos pelo piche e pelo termofixo acabam sendo totalmente distintas. Essa diversidade da estrutura não grafítica fica clara nos exemplos da Fig. 1, que apresenta as imagens obtidas por microscopia eletrônica de transmissão de alta resolução (HRTEM) de dois carbonos classificados como não grafíticos, os quais foram produzidos pelo tratamento a $1000{ }^{\circ} \mathrm{C}$ de uma fonte de carbono grafitizável (a antracita) e de outra não grafitizável (a sucrose).

Confrontando-se as duas imagens, é possível concluir que as propriedades do carbono não grafítico derivado da antracita certamente serão mais próximas das do grafite (ou seja, maior condutividade térmica, menor coeficiente de expansão, melhores propriedades mecânicas, etc.) do que as propriedades do carbono não grafítico obtido da sucrose, tudo em razão da maior orientação (anisotropia) e empacotamento dos grafenos na Fig. 1b. Estruturas similares às dos carbonos da sucrose e da antracita poderiam ser esperadas para os carbonos obtidos dos polímeros termofixos e do piche, respectivamente.

Portanto, verifica-se que fontes de carbono grafitizáveis realmente são as mais vantajosas para a aplicação em refratários, mas fica claro que essa vantagem não está na formação do grafite, e sim no estabelecimento de uma estrutura não grafítica altamente anisotrópica. Contudo, essa 


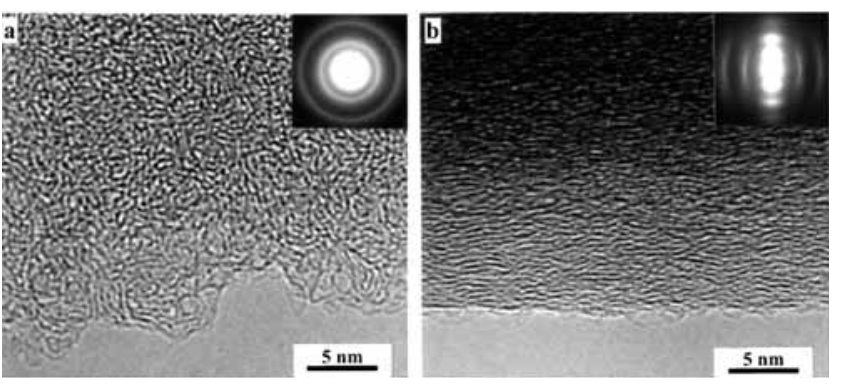

Figura 1: Imagens de HRTEM e padrões de difração de amostras de (a) sucrose e (b) antracita, ambas tratadas a $1000^{\circ} \mathrm{C}$ [13].

[Figure 1: HRTEM images and diffraction patterns from (a) sucrose and (b) anthracite samples, both treated at $1000^{\circ} \mathrm{C}$ [13].]

superioridade das fontes grafitizáveis parece estar chegando ao fim devido ao surgimento dos aditivos denominados agentes grafitizantes. Esses aditivos, cuja composição é baseada em metais de transição, teriam a capacidade de catalisar a cristalização do carbono gerado a partir de fontes não grafitizáveis, isso em temperaturas compatíveis com as do processamento do aço. Essa inovação será apresentada e discutida no capítulo 3 , em que se discorrerá sobre aspectos da composição, cura e carbonização das resinas termofixas

\subsection{Fontes de carbono particuladas}

Sendo geralmente menos afetadas durante a etapa de queima do refratário, e também por fornecerem um carbono com características e propriedades que podem ser muito superiores às do formado pelos ligantes orgânicos, o uso de fontes de carbono particuladas ainda é essencial para que o refratário adquira o teor de carbono adequado e para que ele possa subsistir melhor às condições de trabalho que lhe são impostas. No entanto, essas fontes de carbono sólidas também são capazes de desempenhar outras funções de relevância. Na literatura é possível identificar ao menos seis fontes de carbono particuladas que podem ser cogitadas para a aplicação na composição de refratários: o grafite em "flakes", o grafite microcristalino (grafite amorfo), o negro de fumo ("carbon black"), o coque de petróleo (coque verde), a antracita e as resinas termofixas em pó. Entre todas elas, o grafite na forma de "flakes" é possivelmente a mais usada e a mais interessante. Isso não apenas em razão das já comentadas desejáveis propriedades do grafite, mas também pelo fato de que, sendo um fornecedor direto de um material de elevada pureza e cristalinidade, esses "flakes" passam por alterações mínimas com a queima do refratário (como variações volumétricas devido a reações químicas, transformações de fase, etc.), e nisso também acabam liberando poucos voláteis. Outra vantagem da elevada pureza deste material é a redução do risco de formação de fases indesejáveis em meio ao refratário. Além disso, estando grafitizados desde o princípio e sendo pouco porosos, os "flakes" já serão menos susceptíveis à oxidação logo durante o primeiro aquecimento ao qual o refratário for submetido (a taxa de oxidação do grafite começa a ser significativa apenas a partir de 600$700{ }^{\circ} \mathrm{C}$ [12]). Enquanto isso, mesmo as fontes de carbono grafitizáveis já poderiam estar sendo afetadas, pois suas estruturas anisotrópicas com resistência à oxidação similar à do grafite se desenvolverão apenas a temperaturas elevadas (na faixa de 300 a $600{ }^{\circ} \mathrm{C}$, no caso do piche de alcatrão [9]). Contudo, apesar de todas essas vantagens, a adição dos "flakes" acaba sendo limitada devido a sua geometria lamelar e à baixa molhabilidade do grafite pelos meios dispersantes que participam da composição do refratário, sejam eles líquidos inorgânicos (como a água) ou orgânicos (como o piche e as resinas) [8]. Essas características então dificultam a dispersão dos "flakes", limitam o escoamento das suspensões que o contém, facilitam sua segregação durante o processamento do refratário e prejudicam a densificação deste último $[12,18]$.

No caso da produção de concretos contendo carbono, essa dificuldade se torna ainda mais significativa por ser necessário formar uma suspensão estável e com boa fluidez. Inclusive, a própria fluidez elevada dos concretos acaba servindo como um terceiro estímulo à segregação dos "flakes", visto que, com ela, passa a se pronunciar a grande diferença de densidades existente entre o grafite e os óxidos refratários. Segundo Zhang e Lee [3], os problemas de dispersão e de fluidez causados pela baixa molhabilidade do grafite levam a composição do concreto a demandar um maior teor de líquido. Estes autores exemplificam tal comportamento através dos resultados do trabalho de Teranishi et al, que verificaram que concretos produzidos com "flakes" de grafite exigiriam um teor de água até três vezes superior em comparação ao necessário quando do uso de outras fontes de carbono sólidas de menor cristalinidade, como o negro de fumo e o grafite microcristalino. Como será visto no capítulo 6 , tratamentos superficiais e/ou o uso de certos aditivos poderiam ajudar reduzir os problemas decorrentes da baixa molhabilidade dos "flakes" e de outras frações sólidas. Os "flakes" de grafite podem ser naturais ou sintéticos, sendo estes últimos produzidos pelo tratamento a altas temperaturas de fontes de carbono grafitizáveis, como o coque e a antracita. Entre os parâmetros a serem controlados quanto à qualidade dessas partículas estão suas dimensões [9] e seu teor de cinzas, sendo exigência usual que esses resíduos fiquem abaixo de 10\%p [19]. Além dos "flakes", outro tipo de grafite aplicado à produção de refratários é o grafite microcristalino, também conhecido comercialmente como grafite amorfo, embora tal nomenclatura seja errônea $[20,21]$. Por sua estrutura cristalina mais imperfeita, essa variedade de grafite possui propriedades e características inferiores às dos "flakes", como uma menor resistência à oxidação e uma menor condutividade térmica, ao que ainda se soma o seu maior teor de impurezas [20, 21]. Por outro lado, como comentado anteriormente, a cristalinidade reduzida proporciona benefícios ao favorecer a dispersão das partículas de carbono pelos líquidos e/ou ligantes da composição refratária. Tal capacidade é resultado da maior concentração de grupos polares que acaba se estabelecendo na superfície defeituosa dessas partículas menos cristalinas, o que possibilita que elas desenvolvam uma maior interação com o meio dispersante e, conseqüentemente, uma melhor condição de molhabilidade. Outras possíveis vantagens do 
grafite microcristalino podem ser analisadas pelo trabalho de Chen et al [11], no qual se avalia o desempenho de três composições de refratários de alto teor de carbono compostas por diferentes agregados carbonáceos. Em todas elas, o teor desses agregados foi mantido em $66 \%$ da fração sólida total, sendo os $34 \%$ p restantes constituídos por teores fixos de alumina, "flakes" de grafite e silício metálico em pó. $\mathrm{O}$ grafite microcristalino ganhou destaque por proporcionar a sua composição uma alta resistência mecânica a frio, alta resistência ao ataque por álcalis e pelo ferro líquido, e uma porosidade predominantemente submicrométrica. Segundo os autores, essa porosidade foi justamente um dos fatores que ajudou a minimizar a infiltração e o ataque do metal. O grafite microcristalino também se mostrou muito reativo para com o silício metálico, permitindo a formação de grande quantidade de whiskers de $\mathrm{SiC}$. O seu único aspecto negativo em comparação aos outros agregados avaliados (antracita calcinada e sucata de eletrodos de grafite) foi sua menor condutividade térmica.

Analisando agora o negro de fumo, esta fonte de carbono não é classificada como grafitizável [22], mas ainda assim pode trazer benefícios muito interessantes ao desempenho dos refratários. Em trabalho de Lum et al, citado em um artigo revisão de Rand e McEnaney [23], verificou-se que a adição de negro de fumo à composição de refratários ligados por resinas fenólicas levou a uma redução significativa da produção de voláteis durante o processo de pirólise, um comportamento atribuído à interação desses voláteis com os grupos funcionais presentes na superfície dessas minúsculas partículas de carbono. Já quando bem disperso em meio ao piche, o negro de fumo também teria a capacidade de fortalecer a matriz carbonácea formada com a pirólise [9]. Os teores de negro de fumo que proporcionam tais benefícios aparentam ser sempre de apenas alguns poucos percentuais, o que deve ser levado em consideração ao se determinar a viabilidade de seu uso. Além disso, sendo um subproduto de diversos processos, o negro de fumo também pode apresentar vantagens quanto a custos. O coque de petróleo, também conhecido como coque verde, é um subproduto do processo de craqueamento dos óleos residuais pesados, que são os resíduos do processo de destilação do petróleo $[24,25]$. Essa fonte de carbono apresentaria aspectos significativamente atrativos para a aplicação em refratários, já que possui um alto teor de carbono fixo (90 a $95 \%$ p), baixos teores de cinzas $(0,1$ a $0,2 \%$ p) e de componentes voláteis $(8$ a $10 \%$ p, que ainda pode ser reduzido com a calcinação), além de ser grafitizável [24, 26]. Inclusive, o coque de petróleo costuma ser mais grafitizável que o coque obtido da carbonização do piche derivado do alcatrão [27]. Apesar do seu uso ser comentado em algumas referências, não foram encontrados estudos que avaliassem em detalhes o desempenho dessa fonte de carbono. Porém, acredita-se que ela possuiria algumas características que poderiam torná-la vantajosa frente aos "flakes" de grafite, como partículas de formato não-lamelar e mais facilmente molháveis pelos ligantes da composição refratária, além de um custo reduzido. Tais possibilidades necessitariam ser averiguadas. Das variedades de carvão mineral existentes, a antracita aparenta ser a única com características adequadas para aplicação como um agregado nas composições dos refratários contendo carbono. Porém, o seu uso para tal finalidade provavelmente é viável apenas em países que detém grandes reservas desta fonte de carbono grafitizável e de alta pureza, como os Estados Unidos e a China. Segundo Chen et al [11], a antracita calcinada apresenta como vantagens uma excelente estabilidade volumétrica, boa condutividade térmica, uma alta resistência ao ataque de álcalis e também à erosão causada pelo metal fundido. No entanto, a temperatura do seu processo de calcinação não deve ser excessiva, caso contrário a porosidade do agregado se tornará grosseira e haverá perda de resistência mecânica.

A última fonte de carbono levantada nesta seção são as resinas termofixas na forma de pó que, segundo Zoglmeyer [18] e Gardziella et al [28], teriam capacidade de beneficiar o desempenho do refratário através do aumento da resistência mecânica a verde e da produção de carbono durante a pirólise, e pela redução das emissões de voláteis e da porosidade da estrutura do carbono formado. A redução da porosidade, por sua vez, levaria a ganhos nas propriedades mecânicas do refratário tanto a frio como a quente, em porcentagens que, segundo dados apresentados por Zoglmeyer, poderiam chegar a mais de $300 \%$ para o módulo de ruptura a frio e a quase $50 \%$ para o módulo de ruptura a quente, e isso com adições dessas resinas em teores inferiores a $1,5 \%$ p. As resinas em pó também podem servir como veículo para a incorporação de aditivos ao refratário, como no caso de agentes de cura [28]. Em trabalho de Aneziris et al [10], por exemplo, utiliza-se como ligante uma resina novolaca líquida, sendo que o agente de cura HMTA se encontra incorporado no teor de $28 \%$ p a uma resina novolaca em pó com partículas predominantemente abaixo dos $45 \mu \mathrm{m}$. Cogita-se que o mesmo procedimento poderia ser adotado para o acréscimo de outros aditivos, como os agentes antioxidantes. As novolacas sem dúvida seriam as resinas fenólicas mais interessantes para serem adicionadas na forma de pó, uma vez que elas já são usualmente encontradas no estado sólido e ainda teriam a vantagem de liberar menos voláteis durante a cura em comparação aos resóis (como será discutido no capítulo 3). Como o mecanismo de atuação desse pó provavelmente envolve a sua fusão e migração pela porosidade do refratário a verde, proporcionando assim o preenchimento desta, supõe-se que o peso molecular médio dessas resinas não deva ser demasiado elevado para que elas possam alcançar uma viscosidade relativamente baixa quando fundidas. Concluindo essa seção, foi possível verificar que, das seis fontes de carbono analisadas, apenas a antracita poderia ser descartada por seu possível maior custo e menor disponibilidade no Brasil. Quanto ao negro de fumo e às resinas em pó, acredita-se as duas poderiam ser aplicadas até mesmo em conjunto, pois os teores em que ambas precisariam ser adicionadas para causar os efeitos desejados ainda representariam pouco dentro do teor total de carbono objetivado para a composição que pretende-se desenvolver (10 a 14\%p). No caso de ser necessário optar 
por apenas uma das duas, as resinas em pó possivelmente seriam a melhor escolha por proporcionarem um maior número de benefícios. Já a adição dos "flakes" de grafite seria indispensável por suas propriedades superiores e por sua maior resistência ao primeiro ciclo de aquecimento do refratário. A decisão mais difícil realmente parece estar entre o grafite microcristalino e o coque de petróleo, até mesmo pela falta de informações sobre este último. Sendo possível que os desempenhos desses dois materiais sejam relativamente semelhantes, outros parâmetros como custo podem acabar sendo mais decisivos.

Ainda deve-se considerar que as vantagens da adição dos "flakes" de grafite podem ser ampliadas, isso no caso dos seus problemas quanto à molhabilidade e dispersão puderem ser reduzidos pela aplicação dos aditivos que serão discutidos no capítulo 6 .

\subsection{Fontes de carbono que atuam como ligantes}

Cimentos de aluminato de cálcio, alumina hidratada e diversos outros ligantes inorgânicos são matérias-primas amplamente aplicadas na produção de tijolos e concretos refratários, sendo seu uso vantajoso principalmente pelas facilidades e pelos baixos custos que proporcionam ao processamento e à aplicação desses materiais. No entanto, no caso de refratários destinados ao setor siderúrgico e que deverão permanecer em contato com as escórias fundidas, a presença desses ligantes pode levar a uma significativa queda de desempenho. A primeira causa deste comportamento está na necessidade da adição de água à composição refratária para desenvolver o processo de pega de tais componentes, o que então leva ao aumento da porosidade do revestimento, à inutilização parcial de possíveis antioxidantes metálicos adicionados, e ainda proporciona a hidratação de óxidos como o $\mathrm{MgO}$ e o $\mathrm{CaO}$. Essas reações, por sua vez, provocam intensas expansões volumétricas que, juntamente com o aumento da porosidade, resultarão em prejuízos às propriedades mecânicas do refratário [3]. Já a segunda causa da queda de desempenho está relacionada à própria composição química dos ligantes inorgânicos, pois, no caso destes conterem óxidos como o $\mathrm{Al}_{2} \mathrm{O}_{3}, \mathrm{CaO}$ e $\mathrm{SiO}_{2}$, a formação de fases líquidas nas temperaturas de trabalho do refratário seria facilitada, levando assim à redução da sua resistência à corrosão e de suas propriedades mecânicas a quente [3]. Portanto, todos esses fatores favoreceriam a aceleração do desgaste do revestimento e, conseqüentemente, o agravamento do problema da contaminação do metal. Apesar de hoje ser possível reduzir o nível destes prejuízos através da minimização do teor de ligantes inorgânicos nas composições refratárias (como no caso dos concretos de ultra-baixo teor de cimento), ainda assim compreende-se o grande interesse que existe por substituí-los.

Neste cenário, o uso de fontes de carbono que também desempenhem o papel de ligantes, como o piche de alcatrão e as resinas termofixas, acabaria sendo duplamente vantajoso. Isso porque, além de evitar os problemas causados pelos ligantes inorgânicos, essas fontes ainda poderiam trazer para a matriz do refratário as desejáveis propriedades do carbono, como sua maior resistência às escórias e aos danos por choque térmico. Porém, é necessário estabelecer algumas exigências básicas para a seleção destes ligantes orgânicos $[29,30]$ : que sejam seguros ao ambiente; que possuam um alto teor de carbono em sua composição, e que consigam fixar grande parte dele com a pirólise (ao menos $40 \%$ p); que tenham estabilidade para serem estocados; que tenham boas características quanto a sua fluidez e sua adesão às partículas da fração sólida do refratário, permitindo que a composição deste seja homogênea e se mantenha assim nas etapas posteriores à mistura; e que sejam facilmente acessíveis no mercado e por um preço razoável.

O alcatrão e o piche de alcatrão obtidos do carvão mineral foram os primeiros ligantes orgânicos usados na produção de refratários, e ainda hoje se destacam por sua alta capacidade de fixação de carbono (por volta de $50 \%$ p [31]) e por este ser usualmente do tipo grafitizável. Porém, como são matérias-primas de composição muito diversa, é necessário frisar que o seu nível de grafitização não é constante, existindo até mesmo variedades não grafitizáveis [16]. Outras vantagens importantes do alcatrão e do piche são o baixo custo, a boa adesão que apresentam para com a fração sólida do refratário $[10,31,32]$ e o teor mínimo de água em suas composições. O primeiro inconveniente destes ligantes surge do fato de que, sendo sólidos à temperatura ambiente, eles acabam exigindo que a mistura da composição refratária seja feita sob aquecimento (usualmente, na faixa de 100 a $200^{\circ} \mathrm{C}$ [9]) para que assim possam atingir seu ponto de amolecimento e adquirir a fluidez necessária. Além disso, como eles não perdem esse comportamento termoplástico após a conformação do refratário, a carbonização do mesmo deve ser realizada inicialmente a temperaturas não muito elevadas para que a integridade do produto não seja prejudicada [9]. No entanto, a principal desvantagem do alcatrão e do piche está nas elevadas quantidades de substâncias poluentes e tóxicas, inclusive cancerígenas, que eles acabam por liberar durante a pirólise, sendo os hidrocarbonetos aromáticos policíclicos (HAP's), como o benzopireno, as mais preocupantes $[1,3,13,31]$. Segundo Hampel e Aneziris [32], os piches convencionais costumam apresentar concentrações de benzopireno de 10.000 a $15.000 \mathrm{ppm}$, enquanto teores de $50 \mathrm{ppm}$ já são considerados perigosos. Como alternativas para reduzir/evitar os problemas de salubridade causados por essas substâncias, tem sido feito uso de piches derivados do petróleo (que naturalmente já apresentam teores reduzidos de HAP's e de outras substâncias nocivas $[32,33])$, e também do produto denominado Carbores ${ }^{\circledR} \mathrm{P}$ (da empresa alemã Rütgers SA), que é obtido por meio do beneficiamento do alcatrão de carvão mineral, processo feito justamente com o intuito de minimizar o seu teor HAP's [31]. Além de menos tóxico, o piche de petróleo também teria como vantagem sua maior grafitizabilidade em comparação ao piche de alcatrão, o que o levaria a formar um carbono mais anisotrópico e, portanto, com propriedades superiores [34]. Por outro lado, segundo Hampel e Aneziris [32], o piche de petróleo é desvantajoso por apresentar uma menor capacidade de fixação de carbono, 
comportamento que possivelmente decorre do seu menor teor de compostos aromáticos insolúveis, combinado a uma maior presença de hidrocarbonetos alifáticos. No entanto, assim como também pode ser feito no caso do piche de alcatrão convencional e do $\operatorname{Carbores}^{\circledR} \mathrm{P}$, a adição ao piche de petróleo dos aditivos denominados agentes dehidrogenantes seria capaz de proporcionar aumentos significativos da sua produção de carbono, além de tornar este mais denso, menos poroso e melhorar suas propriedades [35]. O princípio de ação desses agentes está basicamente na sua capacidade de remover o hidrogênio e de formar ligações cruzadas entre as moléculas que compõem o ligante orgânico, dificultando assim a formação de voláteis que contenham carbono [35]. Ou seja, pela literatura consultada, entende-se que essas ligações cruzadas não estariam causando a redução da grafitizabilidade dessas fontes de carbono e, portanto, não estariam prejudicando a anisotropia da estrutura do carbono produzido.

$\mathrm{O}$ enxofre e alguns de seus derivados aparentam serem os agentes dehidrogenantes mais aplicados, ainda existindo outros como nitratos inorgânicos, compostos aromáticos clorinados, ésters e ácidos de Lewis [32]. Boenigk et al [35] apresentam resultados em que a adição de $15 \%$ p de enxofre a uma mistura de ligantes orgânicos proporcionou um aumento de quase $10 \%$ p na fixação de carbono. Porém, não foram encontrados comentários sobre as conseqüências da adição do enxofre e de seus compostos sobre a toxicidade dos voláteis liberados com a queima do refratário, sendo que gases como o $\mathrm{SO}_{2}$ e $\mathrm{H}_{2} \mathrm{~S}$ são considerados perigosos.

Voltando à descrição das variedades de ligantes orgânicos, algumas características básicas do Carbores $^{\circledR} \mathrm{P}$ e da sua versão dissolvida, o Carbores ${ }^{\circledR}$ T10, podem ser observadas na Tabela I. Verifica-se que ambos apresentam teores de benzopireno bem inferiores aos do piche convencional. Apesar da vantagem de ser líquido à temperatura ambiente, a fixação de carbono do Carbores ${ }^{\circledR}$ T10 acaba sendo muito reduzida em comparação à do Carbores ${ }^{\circledR} \mathrm{P}$, o que sem dúvida é uma conseqüência da presença do solvente (cuja composição é desconhecida).

Segundo trabalhos de Aneziris et al [10] e Boenigk et al [35], um ligante formado pela combinação entre essas duas resinas carbonáceas apresentaria muitas vantagens, pois permitiria que a mistura da composição refratária fosse realizada a frio e, sendo ambas as variedades de Carbores grafitizáveis, a matriz de carbono formada acabaria sendo totalmente anisotrópica. Além disso, outras características como porosidade e densidade seriam similares às obtidas com o uso de resinas termofixas nessa função. Também de acordo com esses pesquisadores, tanto o Carbores ${ }^{\circledR} \mathrm{P}$ como o Carbores ${ }^{\circledR}$ T10 teriam um custo inferior ao das resinas fenólicas. Porém, como essa análise foi feita considerando as cotações desses produtos na Europa, deve-se reavaliar essa vantagem diante da necessidade de importação.

Passando-se agora às resinas termofixas, a aplicação destas na produção de refratários já se encontra muito difundida, principalmente nos Estados Unidos e Ásia [35], havendo especialistas que chegam a afirmar que elas já seriam os ligantes mais aplicados na produção de tijolos de $\mathrm{MgO}-\mathrm{C}[31,36]$. Porém, as vantagens que estes polímeros proporcionariam podem ir muito além da questão da sua reduzida toxicidade, sendo também possível mencionar: possibilitam um maior teor de sólidos na composição do refratário, inclusive de partículas de grafite e negro de fumo $[9,28]$; o consumo de energia para o processamento do refratário é reduzido quando do uso de resinas que permitem que o processo de mistura seja realizado a frio [9, 28, 32]; após sua cura, a resina confere uma alta resistência mecânica ao refratário a verde [23]; ao contrário do piche, as resinas não passam por uma fase termoplástica durante o seu aquecimento até a temperatura de pirólise [9, 23, 28, 32], permitindo que a peça refratária mantenha sua resistência e geometria, mesmo que essa seja de grande complexidade; podem colaborar para a redução da porosidade do refratário [18]; produzem pouca fumaça durante a pirólise [37]; sua pirólise pode levar à fixação de maiores porcentagens de carbono [29]; sendo sintéticas, suas propriedades são mais previsíveis; e a grande variedade de resinas permite a escolha do tipo mais adequado para cada aplicação $[9,18,30,38]$. Porém, é possível que todos esses e outros aspectos positivos ainda estejam longe de ser aproveitados em sua totalidade, isso em razão da raridade de esforços que se verifica para o desenvolvimento de resinas termofixas voltadas especificamente às necessidades do setor de refratários, escassez que deve estar sendo ainda mais prejudicial para a evolução dos refratários monolíticos ligados por resinas. Assim, procurando mostrar como as características das

Tabela I. - Descrição das variedades de resinas carbonáceas produzidas a partir do piche de alcatrão pela Rütgers SA [10]. [Table I - Descriptions of the carbonaceous resins varieties produced from coal tar pitch by Rütgers SA [10].]

\begin{tabular}{rcc}
\hline & \multicolumn{2}{c}{ Ligante } \\
\hline \multicolumn{1}{c}{ Características } & Carbores $^{\circledR} \mathrm{P}$ & Carbores $^{\circledR} \mathrm{T} 10$ \\
\hline Descrição & Resina carbonácea em pó & Resina carbonácea líquida \\
Temperatura de transição vítrea $\left({ }^{\circ} \mathrm{C}\right)$ & 213 & - \\
Fixação de carbono (ISO 6998$)(\%)$ & 85,5 & 32 \\
Teor de benzopireno $(\mathrm{ppm})$ & 300 & 300 \\
Granulometria $(<200 \mu \mathrm{m})(\%)$ & 90 & - \\
Viscosidade dinâmica a $20^{\circ} \mathrm{C}(\mathrm{mPa} . \mathrm{s})$ & - & 3200 \\
\hline
\end{tabular}


resinas interferem em seu desempenho para a aplicação em refratários, o próximo capítulo faz uma revisão sobre as bases da síntese, cura e pirólise destes polímeros.

\section{AS RESINAS TERMOFIXAS}

De um modo geral, as resinas termofixas podem ser definidas como substâncias orgânicas de baixo peso molecular que, sendo submetidas a condições propícias e/ ou complementadas com aditivos específicos, começam a sofrer uma série de transformações denominada como processo de cura. Neste processo, as moléculas que compõem a resina passam a reagir entre si, formando então macromoléculas altamente ramificadas que também terminam por se unir através de ligações covalentes, dando origem a um sólido constituído por uma rede molecular tridimensional de grande complexidade, que é justamente a estrutura característica dos polímeros termofixos. Nesta estrutura em que predominam ligações químicas primárias, o movimento relativo das macromoléculas (que proporcionaria ao material a capacidade de fluir) acaba não sendo possível, seja através da ação de solventes ou pelo aumento da temperatura, comportamento que é responsável pelo termo "termofixo". Assim, o aquecimento excessivo (acima de $300{ }^{\circ} \mathrm{C}$ ) leva diretamente à degradação desses polímeros, processo que, em ambientes não demasiado oxidantes, acaba gerando um resíduo carbonáceo em temperaturas superiores a $700{ }^{\circ} \mathrm{C}$ [28]. Para a aplicação desses polímeros na produção de refratários, é interessante que tal processo de degradação seja altamente produtivo, ou seja, capaz de fixar na forma sólida grandes quantidades de carbono. Porém, essa produtividade não é função apenas de variáveis externas, como temperatura e condições do meio, mas também da própria estrutura química do polímero termofixo e, portanto, da resina que lhe deu origem. Entre todas as classes de resinas termofixas existentes, que são distinguíveis basicamente pela composição química, uma se destaca por combinar uma elevada capacidade de fixação de carbono com as vantagens de um custo acessível e de uma grande disponibilidade no mercado atual. Esta é a classe das resinas fenólicas, que podem ser definidas como sendo as resinas produzidas a partir de reações entre aldeídos e o fenol, ou derivados do fenol. Por essas vantagens tão decisivas, ainda mais considerando a competição com produtos de baixo custo como o piche, as resinas fenólicas serão o foco deste capítulo, o qual consiste em uma síntese básica do artigo revisão "Resinas termofixas e a produção de refratários contendo carbono" [39], mas fazendo-lhe alguns complementos.

\subsection{A composição das resinas fenólicas e algumas características}

Apesar da existência de uma enorme diversidade de aldeídos e de compostos derivados no fenol, predominam na produção das resinas fenólicas os reagentes mais simples, o formaldeído (metanal, $\mathrm{CH}_{2} \mathrm{O}$ ) e o fenol (hidroxibenzeno, $\mathrm{C}_{6} \mathrm{H}_{5} \mathrm{OH}$ ), que dão origem às resinas fenólicas fenol- formaldeído. Por uma série de motivos, como custos e liberação de odor, o uso de outros reagentes é pouco comum e limitado à produção de resinas destinadas a aplicações mais específicas [28]. Essencialmente, a síntese das resinas fenol-formaldeído é compreendida por sucessivas reações de condensação, as quais geram água como principal subproduto e podem ser divididas em duas etapas. Na primeira etapa, o formaldeído reage com o fenol nas posições orto e/ou para de seu anel aromático, dando origem a diversos compostos do tipo metilol-fenol. Na segunda etapa, os oligômeros da resina começam a se formar na medida em que os metilóis-fenóis reagem entre si e também com o fenol livre ainda disponível. A proporção entre formaldeído e fenol usada na síntese, representada aqui pela razão molar F/P ("Formaldehyde"/“Phenol"), tem grande impacto sobre as características dessas resinas, servindo para distingui-las em dois grupos principais: quando $\mathrm{F} / \mathrm{P} \geq 1$, tem-se os chamados resóis, enquanto $\mathrm{F} / \mathrm{P}<1$ leva à produção de novolacas. Devido ao excesso de formaldeído em sua síntese, os resóis são constituídos usualmente por misturas entre metilóisfenóis, oligômeros diversos (dímeros, trímeros, etc.) e teores residuais de fenol e formaldeído não reagidos [28]. No caso dos resóis líquidos, permite-se que as reações de condensação ocorram até que se produzam moléculas com, no máximo, dois núcleos aromáticos [40], sendo que a água formada nessas reações pode tanto permanecer na composição da resina na função de solvente, como pode ser substituída por outros solventes (como alcoóis, por exemplo). Já os oligômeros que compõem os resóis sólidos podem chegar a ter até três ou quatro núcleos aromáticos [40], sendo a água das reações de condensação extraída para a obtenção da resina solidificada. $O$ ponto de amolecimento dos resóis sólidos costuma ser de até $70{ }^{\circ} \mathrm{C}$ [29].

Passando-se às novolacas, o excesso de fenol em sua síntese leva rapidamente ao início da formação dos oligômeros. Estes costumam apresentar de dois a treze núcleos aromáticos em suas estruturas, sendo seis núcleos o valor médio usual, o que acaba por torná-los hidrofóbicos [40]. Portanto, as novolacas puras são encontradas no estado sólido à temperatura ambiente. As novolacas apresentam seu ponto de amolecimento na faixa de 70 a $100{ }^{\circ} \mathrm{C}$, temperatura que ainda pode ser reduzida pelo aumento do teor de fenol livre na composição [28]. Porém, nesta escolha deve-se considerar a toxicidade do fenol. Assim, comparando os dois tipos de resinas fenólicas em suas formas puras, e tendo em vista a aplicação em refratários, os resóis levariam vantagem sobre as novolacas por já poderem ser encontrados como líquidos de baixa viscosidade, o que então permite que a sua mistura com a fração sólida da composição refratária seja feita à temperatura ambiente. No entanto, o uso de solventes, ainda mais se somado ao controle sobre a distribuição de peso molecular da resina, pode permitir a produção de novolacas líquidas e com viscosidades reduzidas. Zoglmeyr [18], por exemplo, apresenta gráficos de viscosidade em função da temperatura em que se verificam novolacas em solução e resóis atingindo viscosidades similares. Além disso, a aplicação dos resóis na produção de refratários costuma ser 
problemática pela presença da água em suas composições e pela sua maior sensibilidade às condições e ao tempo de estoque [5]. A água acaba sendo prejudicial não somente quando o material refratário é passível de sofrer hidratação, como também por limitar o uso e a eficácia de antioxidantes metálicos como o alumínio e o silício (que são inutilizados quando hidratados) e por levar ao aumento da porosidade do material. Assim, ao menos para reduzir os problemas de hidratação, também pode ser interessante substituir a água dos resóis por outros solventes.

\subsubsection{A viscosidade e o uso de solventes}

A viscosidade da resina termofixa é um parâmetro muito visado por seu impacto sobre a processabilidade das composições refratárias, sendo possível variá-lo pela alteração da distribuição de pesos moleculares, pelo acréscimo de solventes e pela aplicação de temperatura. Contudo, para definir a viscosidade desejada à resina, é interessante analisar que tanto altas como baixas viscosidades proporcionam importantes vantagens e desvantagens para o processamento e mesmo para as propriedades do refratário. Além de permitirem que a mistura da composição refratária seja realizada a frio, as resinas de baixa viscosidade também possuem a capacidade de recobrir e molhar os agregados refratários de forma rápida e eficaz [18]. Isso significa que poderão ser usados equipamentos de mistura de menor potência e também que a duração desta etapa poderá ser reduzida, diminuindo assim os custos de produção. Adicionalmente, com a composição final apresentando uma maior fluidez e compressibilidade, qualquer processo de conformação seria facilitado. No caso de resinas mais viscosas, apesar de dificultarem e prolongarem o processo de mistura, por outro lado elas permitem um maior teor de sólidos na composição refratária (o que incluiria os "flakes" de grafite) e, na pirólise, ainda teriam capacidade de atingir maiores porcentagens de fixação de carbono [18], dois aspectos muito benéficos às propriedades finais do produto. Portanto, verifica-se que realmente é preciso buscar um equilíbrio nos valores de viscosidade da resina termofixa para que os ganhos em processabilidade não sejam perdidos por prejuízos inaceitáveis ao desempenho do refratário, ou vice-versa.

Analisando agora os métodos para alterar a viscosidade, pequenas elevações da temperatura já promoveriam aumentos significativos na fluidez de algumas resinas (como é possível observar por alguns gráficos discutidos em [18]) a um custo que poderia ser aceitável pelo benefício à processabilidade. Porém, essa opção certamente adéquase mais às novolacas, pois a cura dos resoles já pode ser muito acelerada mesmo com variações de temperatura em intervalos abaixo dos $100{ }^{\circ} \mathrm{C}$, o que então dificultaria o controle do tempo de trabalhabilidade da composição. A diminuição do peso molecular da resina pode levar a expressivas reduções de sua viscosidade. No entanto, o uso isolado desse método dificilmente será viável devido às conseqüências para a cura e para a pirólise do termofixo: além de necessitarem de um processo de cura mais demorado e poderem levar a uma menor fixação de carbono, resinas de menor peso molecular também exigiriam o aumento do teor do agente de cura (no caso de novolacas) e produziriam mais água como subproduto das reações de cura (no caso de resóis). Porém, o peso molecular ainda pode precisar ser alterado, pois ele também exerce grande efeito sobre o terceiro método para a redução da viscosidade, o qual envolve o uso de solventes. É possível verificar essa relação entre o peso molecular e a solubilidade das resinas fenólicas através da Fig. 2, principalmente no comportamento dos resóis. Quanto às novolacas, não foi encontrada na literatura qualquer correlação direta entre as características destas resinas e os tipos de solventes que mais lhe são adequados. Algumas fontes apenas citam que os solventes mais comuns às novolacas seriam a acetona, metanol, etanol, isopropanol, $\mathrm{N}, \mathrm{N}$-dimetilformamida, 1,4-dioxano, tetrahidrofurano, 1-butanol, metil-etil-cetona, clorofórmio, cloreto de metila e o dimetilsulfóxido [28, 41]. Além do peso molecular, outros aspectos da resina também podem ter importante efeito sobre a sua solubilidade: de acordo com Chanda e Roy [40], por exemplo, os resóis sintetizados pela catálise com $\mathrm{NaOH}$ seriam solúveis em água, enquanto a catálise com amônia os torna mais solúveis em alcoóis.

$\mathrm{Na}$ seleção do solvente mais apropriado à composição refratária, é necessário estar atento a características como sua viscosidade, sua capacidade de promover reações de hidratação e os riscos associados ao seu uso. A questão da hidratação é particularmente importante, pois é a principal justificativa para substituir a água por qualquer outra substância, uma vez que, tomando-se os aspectos de custos, riscos associados e disponibilidade, a água certamente sempre acabaria sendo o solvente mais vantajoso.

Para evitar o problema da hidratação dos refratários de doloma, Gardziella et al [28] sugerem o uso de resinas que possuam teores de água inferiores a $0,3 \%$ p e que também não produzam água durante as reações de cura (o que excluiria os resóis). A aplicação do etileno glicol como solvente é desaconselhada, mas os autores não esclarecem como essa substância causa a hidratação. Uma das hipóteses levantadas seria a de que o etileno glicol poderia se polimerizar em polietileno glicol através da condensação dos seus grupos $\mathrm{OH}$, o que então levaria à formação de água. Contudo, não foi possível confirmar se haveria condições para que essa reação ocorra durante o processamento da composição refratária. Também segundo Gardziella et al, o álcool furfurílico anidro seria o solvente mais adequado para a preparação das soluções de novolacas aplicadas à produção de refratários de doloma, pois, além de não causar hidratação, ele também não liberaria odores fortes, um problema que acaba limitando o uso de outros produtos. No entanto, de acordo com os próprios autores, o álcool furfurílico apresentaria o inconveniente de um custo relativamente elevado. Algumas características físicas desse e dos demais solventes comentados anteriormente são apresentadas na Tabela II abaixo, juntamente com seus códigos NFPA 704, pelos quais é possível comparar essas substâncias quanto ao nível dos riscos de toxicidade (T), 
Tabela II - Características físicas (à temperatura ambiente) e classificação pelo código NFPA 704 de alguns possíveis solventes para as resinas fenólicas [42].

[Table II - Physical characteristics (at room temperature) and NFPA 704 classification of some likely solvents for phenolic resins [42].]

\begin{tabular}{|c|c|c|c|c|c|}
\hline & $\begin{array}{c}\text { T ebulição } \\
\left({ }^{\circ} \mathrm{C}\right)\end{array}$ & $\begin{array}{l}\text { Viscosidade } \\
(\mathrm{mPa} . \mathrm{s})\end{array}$ & $\begin{array}{c}\text { NFPA } \\
(\mathrm{T}, \mathrm{I}, \mathrm{R})^{*}\end{array}$ & $\begin{array}{l}\text { Ponto de fulgor em } \\
\text { vaso fechado }\left({ }^{\circ} \mathrm{C}\right)\end{array}$ & $\mathrm{T}$ de ignição $\left({ }^{\circ} \mathrm{C}\right)$ \\
\hline Etilenoglicol & 197,6 & 20 & $1,1,0$ & 111 & 413,0 \\
\hline Dimetilsulfóxido & 189 & 2,0 & $1,1,0$ & 87,8 & 215,0 \\
\hline Clorofórmio & 61,2 & 0,55 & $2,0,0$ & Não inflamável & Não inflamável \\
\hline $\mathrm{N}, \mathrm{N}$-dimetilformamida & 153 & 0,92 & $1,2,0$ & 57,8 & 445,3 \\
\hline Etanol & 78,3 & 1,11 & $0,3,0$ & 12,8 & 365,2 \\
\hline 1-butanol & 117,7 & 2,6 & $1,3,0$ & 28,9 & 343,6 \\
\hline Metanol & 64,5 & 0,55 & $1,3,0$ & 12,2 & 464,2 \\
\hline Isopropanol & 82,5 & 2,05 & $1,3,0$ & 11,7 & 400,0 \\
\hline Metil-etil-cetona & 79,6 & 0,43 & $1,3,0$ & $-6,6$ & 516,5 \\
\hline Acetona & 56,1 & 0,33 & $1,3,0$ & $-17,8$ & 465,4 \\
\hline Furfural & 161,7 & - & $3,2,0$ & 60,0 & 393,0 \\
\hline Álcool furfurílico & 170,0 & 4,6 & $3,2,1$ & 65 & 391,4 \\
\hline 1,4-dioxano & 101,3 & - & $2,3,1$ & 12,2 & 180,1 \\
\hline Tetrahidrofurano & 66 & 0,48 & $2,3,1$ & $-14,4$ & 321,0 \\
\hline Cloreto de metila & $-24,2$ & 0,18 & $2,4,0$ & $<0$ & 632,7 \\
\hline
\end{tabular}

*Índices de toxicidade (T), inflamabilidade (I) e reatividade (R), que variam de 0 (risco mínimo) até 4 (risco máximo).

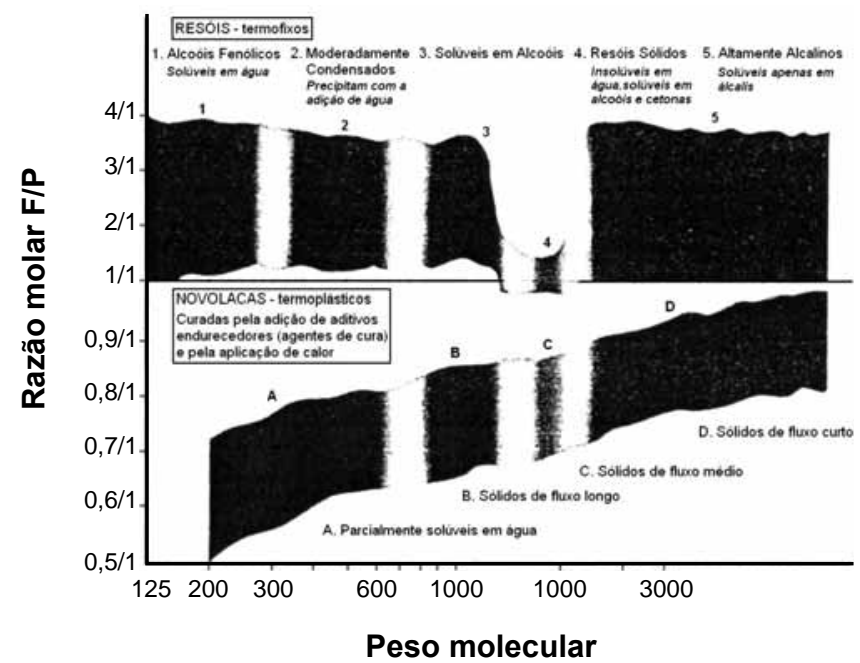

Figura 2: Características quanto ao estado físico e à solubilidade das resinas fenólicas em função da razão F/P e da massa molecular (adaptado de [30]).

[Figure 2: Characteristics regarding the physical state and the solubility of phenolic resins as functions of their $F / P$ ratio and molecular mass (adapted from [30]).]

inflamabilidade (I) e reatividade (R) associados ao seu uso.

Observa-se que os riscos associados ao álcool furfurílico são elevados em termos de toxicidade e inflamabilidade, enquanto o etileno glicol apresentaria o melhor conjunto de aspectos entre todos os solventes analisados, isso apesar da sua viscosidade relativamente alta. Quanto à possibilidade de que ele cause reações de hidratação, ainda se está cogitando que estas poderiam ocorrer apenas a temperaturas mais elevadas e/ou que não seriam tão intensas quanto às causadas pela adição direta da água, o que já poderia tornar o uso do etileno glicol compensador. Tais possibilidades necessitam ser averiguadas. Também ainda seria necessário comparar essas substâncias quanto aos seus custos e necessidades específicas (como condições de estocagem), mas já é possível concluir que o etileno glicol possuiria alguns dos atributos básicos para a sua aplicação como solvente das resinas que constituem as composições refratárias.

\subsection{A cura da resina}

As reações envolvidas no processo de cura das resinas fenólicas, tanto no caso de resóis como de novolacas, ainda não são completamente compreendidas. Isso se deve às dificuldades para se analisar materiais que, além de complexos em suas estruturas químicas, não são susceptíveis à fusão ou mesmo à dissolução. No entanto, algumas noções básicas sobre os processos de cura já são suficientes para compreender suas conseqüências, principalmente sobre a capacidade de fixação de carbono desses termofixos.

No caso dos resóis, os processos que levam à cura envolvem basicamente a retomada das reações de síntese, visto que os resóis ainda permanecem com uma grande quantidade de grupos reativos (os metilóis) depois que são sintetizados. É justamente essa característica que explica a menor estabilidade dessas resinas com o tempo de estoque e a necessidade de armazená-las a baixas temperaturas [5]. 
Tabela III - Efeitos do teor de HMTA no processo de cura das novolacas (adaptado de [28]).

[Table III - Effects of the HMTA content on the novolac curing process (adapted from [28]).]

\begin{tabular}{ccccccc}
\hline $\begin{array}{c}\text { Razão em peso } \\
\text { Novolaca/HMTA }\end{array}$ & $\begin{array}{c}\text { Teor de } \\
\text { HMTA }\end{array}$ & pH & $\begin{array}{c}\text { Temperatura de } \\
\text { reação }\end{array}$ & $\begin{array}{c}\text { Taxa de } \\
\text { reação }\end{array}$ & $\begin{array}{c}\text { Estruturas com } \\
\text { nitrogênio retidas }\end{array}$ & $\begin{array}{c}\text { Densidade de } \\
\text { ligações cruzadas }\end{array}$ \\
\hline $94 / 6$ & Baixo & + Ácido & Baixa & Rápida & Poucas & Baixa \\
$80 / 20$ & Alto & Ácido & Alta & Lenta & Muitas & Alta \\
\hline
\end{tabular}

Esse problema inclusive se acentua com o aumento da razão F/P usada em sua síntese [30].

De acordo com Lemon [30], existem três métodos básicos para catalisar a cura dos resóis: aquecendo a resina até temperaturas entre 60 e $250{ }^{\circ} \mathrm{C}$ (mais usualmente, entre 100 e $\left.160{ }^{\circ} \mathrm{C}\right)$; à temperatura ambiente, com a adição de ácidos como o sulfúrico, o fosfórico, o sulfônico, entre outros, que causariam um processo de cura exotérmico; e para resóis altamente alcalinos (ver Fig. 2), pela adição de ésters à temperatura ambiente, levando a um processo de cura pouco exotérmico. Além desses três métodos, Gardziella et al [28] também acrescentam a cura pela adição de substâncias básicas à resina. Ou seja, qualquer variação de $\mathrm{pH}$, tanto para ácido como para básico, levará os resóis a desenvolverem suas reações de polimerização. Contudo, no caso dos resóis aplicados à produção de refratários, o método de aquecimento seria o mais convencional [43]. É necessário destacar que, estando envolvidas as mesmas reações de condensação da síntese, a cura dos resóis por qualquer um dos quatro métodos citados também acabará levando à formação e liberação de significativas quantidades de água, o que pode ser muito prejudicial aos refratários contendo $\mathrm{MgO}$ e/ou $\mathrm{CaO}$.

Quanto às novolacas, por não possuírem formaldeído livre ou grupos funcionais reativos em seus oligômeros, as suas reações de cura se desenvolvem apenas se lhes forem adicionados agentes de cura como o hexametilenotetramina (HMTA), bisoxazolinas, bisbenzoxazinas, derivados do fenol, ou mesmo o próprio resol sólido, sendo o HMTA o aditivo mais amplamente utilizado [28].

O HMTA $\left(\mathrm{C}_{6} \mathrm{H}_{12} \mathrm{~N}_{4}\right)$ é encontrado como um pó branco, muito solúvel em água e menos solúvel em alcoóis como o etanol e o metanol, sendo propenso a explodir quando está nessa forma de pó [28]. No entanto, o seu manuseio pode ser evitado se ele já vier misturado à própria resina. Como as reações entre o HMTA e a novolaca ocorrem apenas com o aquecimento a temperaturas superiores a $100{ }^{\circ} \mathrm{C}$ [30], não há o risco de que a cura ocorra de forma espontânea, e assim a resina aditivada continua tendo estabilidade para ser estocada em condições ambientes. As complexas reações que ocorrem no processo de cura das novolacas com o HMTA são apresentadas em detalhes por Gardziella et al [28], sendo interessante mencionar que tais reações levam o termofixo a adquirir grupos nitrogenados e não geram água como um subproduto. Assim, diferentemente dos resóis, os problemas de hidratação que o uso de novolacas nas composições refratárias poderia causar estariam ligados unicamente ao líquido usado como seu solvente, o qual sempre poderá ser modificado. Devido ao tipo de catalisador utilizado em sua síntese, as novolacas acabam apresentando um $\mathrm{pH}$ moderadamente ácido, o qual também favorece a aceleração das reações envolvidas no processo de cura. No entanto, o HMTA é um composto básico. Conseqüentemente, o processo de cura será mais lento quanto maior for o teor de HMTA adicionado à resina. Essa e outras conseqüências da variação do teor de HMTA podem ser observadas nos exemplos apresentados pela Tabela III abaixo.

Para realizar a conformação do refratário é necessário estar atento ao tempo de trabalhabilidade que a resina proporciona, o qual é dependente da velocidade do seu processo de cura. Porém, a determinação desse parâmetro pode ser complexa, já que depende não somente da resina e do seu método de cura, mas também das características do refratário. $\mathrm{O}$ controle da cura dos resóis pelo ajuste do $\mathrm{pH}$, por exemplo, é dificultada devido ao próprio $\mathrm{pH}$ do refratário [5]. Segundo Rand e McEnaney [23], até mesmo a cura de novolacas (com HMTA) seria acelerada na presença de $\mathrm{CaO}$ e $\mathrm{MgO}$. De qualquer modo, acredita-se que as novolacas sempre proporcionariam um processo de cura mais facilmente controlável em comparação aos resóis, isso uma vez que a ativação do HMTA estaria ocorrendo apenas em temperaturas acima de $100^{\circ} \mathrm{C}$, sendo que a temperatura, ao contrário do $\mathrm{pH}$ da composição refratária, é um parâmetro de fácil ajuste. Porém, ainda seria preciso avaliar se, no caso das novolacas líquidas, essa temperatura não estaria variando de acordo com o solvente utilizado.

\subsection{A pirólise do polímero termofixo}

Assim como a cura da resina, a pirólise dos polímeros termofixos também é um processo complexo e até hoje não completamente compreendido, estando envolvidas nesta transformação uma grande diversidade de reações de condensação, oxidação, desidratação e decomposição. É interessante observar que, apesar de tais reações provocarem uma extensa quebra de ligações químicas, todo o processo de pirólise desses materiais se desenvolve no estado sólido. Este é um indicativo claro de que a mobilidade das estruturas moleculares permanece sendo muito restrita, fator que certamente favorece a incapacidade de grafitização do carbono obtido a partir desses polímeros, uma vez que dificulta a formação e o alinhamento de planos extensos de grafenos. Já no caso do piche e de outras de fontes de carbono graftizáveis, a pirólise ocorre com o material estando ao menos parcialmente fundido e, portanto, com suas moléculas apresentando uma mobilidade significativa. Apesar da complexidade deste processo, ainda é possível 
observar correlações claras entre as características da resina original e o resultado de sua pirólise. Entre os aspectos do termofixo que impactam em sua capacidade de fixação de carbono, ganham destaque a configuração molecular dos oligômeros da resina, a densidade de ligações cruzadas desenvolvida com a cura e a presença de heteroátomos. A relevância do primeiro aspecto está ligada a sua influência sobre a própria configuração da estrutura tridimensional do termofixo curado, como sua simetria e empacotamento, visto que essas e outras características afetam a permeabilidade dessa estrutura aos voláteis que estarão participando das reações da pirólise. Além disso, elas também poderão exercer uma influência significante sobre as próprias características do carbono produzido.

Um exemplo que pode ser citado para demonstrar a importância do efeito da estrutura molecular é o caso da resina fenólica sintetizada com o 3,5-dimetilfenol em lugar do fenol comum. De acordo com a literatura, tal resina se diferencia das demais por conseguir gerar um carbono com alguma capacidade de grafitização [44]. Por outro lado, essa resina também demonstra ser mais sensível ao oxigênio (o que diminui a produtividade de sua pirólise) e, apesar da grafitizabilidade, o carbono que produz costuma apresentar propriedades mecânicas inferiores às dos obtidos a partir de resinas fenol-formaldeído convencionais [44, 45]. Assim, verifica-se que uma modificação relativamente simples na estrutura da resina (nesse caso, a adição de dois grupos metis ao fenol) já pode alterar significativamente o comportamento tanto do termofixo como do carbono. A densidade de ligações cruzadas do termofixo está diretamente relacionada à dificuldade para a formação de voláteis contendo carbono durante a pirólise. É possível deduzir que uma maior densidade dessas ligações levará à redução da produção de compostos gasosos e, portanto, a uma maior fixação de carbono pelo termofixo, já que o número de ligações que precisariam ser quebradas para liberar moléculas pequenas se torna maior. A densidade de ligações cruzadas pode ser aumentada por dois caminhos básicos: pela intensificação do processo de cura (adicionando um maior teor do agente de cura, por exemplo), ou não alterando a cura e utilizando-se resinas de maior peso molecular, já que de ambas as formas acaba-se aumentando a quantidade de ligações primárias no polímero. Inclusive, esse segundo caminho esclarece um dos motivos para que resinas de maior viscosidade (a qual usualmente está atrelada a um maior peso molecular) acabem levando a maiores porcentagens de fixação de carbono [30].

Quanto à presença de heteroátomos na estrutura da resina curada, grandes concentrações de oxigênio seriam naturalmente prejudiciais, já que esse átomo forma ligações químicas instáveis $[28,46]$, as quais acabarão sendo mais facilmente rompidas com o aumento da temperatura. Assim, a geração de voláteis que contém carbono se intensifica, diminuindo, conseqüentemente, a sua fixação. Neste aspecto, as resinas resóis estariam em desvantagem em relação às novolacas, pois sua estrutura curada pode conter ligações do tipo éter. De acordo com as observações feitas por Gardziella et al $[28,46]$ em relação ao comportamento da fixação de carbono dos resóis, o problema da presença do oxigênio no termofixo aparenta ser significativo principalmente quando a própria atmosfera da pirólise já é oxidante. Ao contrário do oxigênio, a presença do nitrogênio na estrutura do polímero talvez pudesse favorecer maiores porcentagens de fixação de carbono. Segundo trabalho de D. Mang e H.P. Boehm, citado por Gardziella et al $[28,46]$, o nitrogênio atuaria como um estabilizante para os carbonos não grafíticos, tornando-os mais resistentes contra a oxidação. Caso essa capacidade do nitrogênio for significativa nas condições de processamento dos refratários contendo carbono, o uso de altos teores de HMTA para a cura das novolacas seria então duplamente vantajoso, pois proporcionaria uma estrutura mais rica em nitrogênio e com uma maior densidade de ligações cruzadas (ver Tabela III).

Quanto à influência das condições do meio externo sobre os resultados da pirólise, a concentração de oxigênio talvez seja o fator mais preocupante. No entanto, é interessante observar que variações na concentração de oxigênio de apenas alguns percentuais podem não ser tão relevantes para a degradação da resina em meio ao refratário como são para o caso da pirólise da resina pura. Isso porque, no caso do refratário, a taxa de oxidação também é controlada pela capacidade de difusão do oxigênio pela porosidade da sua estrutura. Inclusive, segundo Hampel e Aneziris [32], esse mesmo motivo leva as taxas de oxidação do carbono isotrópico formado pela resina em meio ao refratário a serem muito similares às do carbono anisotrópico formados pelos piches, isso embora o último devesse apresentar uma resistência à oxidação superior. Assim, quanto à característica de resistência à oxidação, a capacidade do ligante para reduzir a porosidade aberta do refratário pode ser mais importante do que sua capacidade de grafitização.

\subsubsection{Agentes grafitizantes}

Conseguir desenvolver a capacidade de grafitização do carbono derivado dos polímeros termofixos seria um passo essencial para efetivamente torná-los os substitutos ideais do piche na composição dos refratários contendo carbono e, de fato, esse desafio tem sido o tema de diversas pesquisas pelo mundo. Compressão mecânica, incidência de radiações, aplicação de campos magnéticos, entre outros tipos de estímulos, já foram testados para incentivar a cristalização dos carbonos não grafíticos. Porém, o único método que tem alcançado sucessos significativos e que, ao mesmo tempo, seria tecnicamente viável para a produção de refratários, aparenta ser o método de grafitização catalítica. A grafitização catalítica consistiria basicamente na adição à fonte de carbono não grafitizável de metais ou compostos metálicos que, com o tratamento do sistema a temperaturas elevadas, conseguiriam interagir com o carbono não grafítico formado, levando-o à grafitizar. De acordo com os trabalhos de A. Oya e S. Otani, que possivelmente foram os pesquisadores que mais exploraram os processos de grafitização catalítica até a atualidade, essa interação do agente grafitizante com o carbono pode ocorrer por meio de dois mecanismos principais: formação-decomposição: o 
metal reage com o carbono e forma seu respectivo carbeto, o qual, se a temperatura for propícia, acaba se decompondo em grafite e no metal elementar (que novamente fica disponível para reagir); e dissolução-precipitação: o carbono não grafítico vai sendo continuamente dissolvido na partícula de metal, sendo depois precipitado na estrutura como carbono grafite. A obra desses pesquisadores, desenvolvida entre os anos de 1970 e 1990, é bem extensa e analisa a ação grafitizante de uma grande diversidade de metais, sendo as resinas fenólicas a principal fonte de carbono não grafítico utilizada. No entanto, é possível ter uma noção geral dos principais resultados e conclusões por eles alcançados por meio de um artigo de 1979 [47] e outro de 1982 [48], que descrevem em detalhes esses dois mecanismos de grafitização e listam os metais que atuam por cada um. Apesar de realmente terem comprovado a ação grafitizante de vários metais, como o níquel, o alumínio e o ferro, os métodos desenvolvidos por esses pesquisadores não obtiveram sucesso por não conseguirem que a grafitização ocorresse de forma homogênea pela amostra de carbono. As regiões grafitizadas acabavam ocorrendo apenas ao redor dos pontos onde as partículas de metal (usualmente, com granulometria de 100 mesh) se encontravam inicialmente. Além disso, o teor necessário do aditivo muitas vezes era elevado (até $30 \%$ p) e a fase grafítica propriamente dita costumava se formar somente com tratamentos a temperaturas acima de $1600{ }^{\circ} \mathrm{C}$. Abaixo disso, surgia apenas uma fase de limitada organização cristalina, denominada como fase turbostrática. O método de grafitização catalítica continuou sem apresentar resultados significativos até o ano de 2001, quando foi publicada uma patente desenvolvida pelos pesquisadores Bartha, Jansen e Daldrup [49], da empresa de refratários alemã Refratechnik. De acordo com essa patente e com um artigo recente de Jansen [50], seria possível levar o carbono produzido pela resina termofixa em meio ao refratário a atingir um alto grau de grafitização por meio da aditivação da resina com diversos compostos metálicos (em teores de 0,1 a $10 \%$ p), e com o posterior tratamento da composição refratária em temperaturas inferiores a $1000{ }^{\circ} \mathrm{C}$. Esses compostos metálicos poderiam ser óxidos, sais ou compostos organometálicos (metaloenos, metal-benzoatos, naftanatos, etc.) de metais de transição como níquel, cobre, ferro, entre outros. Um dos requisitos da técnica é que o agente grafitizante precisa estar disponível como molécula nas temperaturas em que a resina está iniciando o seu processo de carbonização (de 400 a $500^{\circ} \mathrm{C}$ ), condição que poderia ser conseguida adicionando-o na forma de soluções ou como um pó muito fino, sendo que o pó poderia ser aplicado tanto a seco como em suspensão. A patente e o artigo apresentam padrões de difração de raios $\mathrm{X}$ para comprovar a formação do pico referente à fase grafítica a $26,5^{\circ}$ e bem definido, sendo que no artigo podem ser observadas micrografias desta fase. Para exemplificar os benefícios da grafitização, a patente exibe os resultados obtidos com a avaliação de duas composições de tijolos de $\mathrm{MgO}-\mathrm{C}$, sendo que em uma delas a resina foi aditivada com $1 \%$ p do agente grafitizante ferroceno. Após a queima, a composição aditivada apresentou menores módulo elástico e porosidade, e maior resistência à compressão a frio, à flexão a frio e à oxidação $\left(\mathrm{a} 1000{ }^{\circ} \mathrm{C}\right)$, além de uma maior capacidade de fluir a altas temperaturas (o que facilitaria o alívio de tensões e, portanto, reduziria os danos por choque térmico). $\mathrm{O}$ artigo de Jansen também apresenta os resultados das propriedades mecânicas a quente de duas composições similares às que a patente havia analisado, sendo que os resultados de trabalho de fratura para a composição aditivada chegam a ser superiores em mais de $300 \%$ em relação à composição refratária comum. A patente cita o uso dos agentes grafitizantes tanto para o caso de resóis como de novolacas e, embora não fique claro nos exemplos de aplicação apresentados (pois os autores usam o termo secagem ao invés de cura), acredita-se que sempre é permitido que as resinas curem antes que o refratário seja submetido ao tratamento térmico. As razões que levaram essa técnica a ser tão eficaz já a temperaturas tão baixas não foram reveladas. Porém, a necessidade de dispor dos agentes grafitizantes como moléculas no momento da carbonização aparenta ser um indício de que os mecanismos de grafitização atuantes não seriam semelhantes àqueles propostos por Oya $\mathrm{e}$ Otani, principalmente no caso do mecanismo de dissoluçãoprecipitação. Assim, comprovando-se a veracidade da técnica de grafitização catalítica apresentada por Jansen et al, seria ainda necessário estudar as causas desse fenômeno

\subsection{Visão geral}

De acordo com o que foi apresentado e discutido neste capítulo a respeito das resinas fenólicas, pôde-se observar que as novolacas apresentariam, a princípio, o conjunto de características mais positivo para a produção de refratários $\mathrm{MgO}-\mathrm{C}$. No entanto, para confirmar tal favoritismo, ainda seria necessário encontrar um solvente para essas resinas que se encaixasse nos requisitos quanto à toxicidade, volatilidade e custo, e que, sendo adicionado em quantidades coerentes, conseguisse proporcionar a viscosidade almejada (visto que, em excesso, o solvente causaria o aumento da porosidade e a queda da fixação de carbono). Considerando a produção de concretos refratários que utilizassem as resinas como ligante, as novolacas também seriam mais apropriadas, pois permitiriam um melhor controle sobre os tempos de trabalhabilidade e de endurecimento do concreto, e sua viscosidade não é tão susceptível a sofrer alterações quanto a dos resóis. Segundo Zhang e Lee [3], é justamente a dificuldade de dominar esses parâmetros que tem atrapalhado o desenvolvimento de concretos compostos por resinas. Além disso, eles também citam os problemas do alto teor de resina necessário $(>10 \%$ p) para dar ao concreto a fluidez adequada (o que acaba levando ao aumento da sua porosidade) e da dificuldade para dispersar partículas cerâmicas em meio a um líquido orgânico. Quanto a essas duas limitações, acredita-se que o uso dos aditivos que serão apresentados no capítulo 6 poderia auxiliar a contorná-las. Desenvolver concretos resinados que atinjam um desempenho satisfatório seria um grande avanço para os refratários contendo carbono, visto os prejuízos causados pelos ligantes inorgânicos comentados na seção 2.3. 
Ademais, os concretos representam importantes vantagens tanto aos produtores como aos consumidores de refratários, uma vez que dispensam as etapas de moldagem e préqueima, agilizam a instalação do revestimento e melhoram a qualidade de seu acabamento devido à ausência de juntas. Portanto, espera-se que cada vez mais os refratários préconformados sejam preteridos em favor dos monolíticos, sendo assim indispensável que os centros de pesquisa acompanhem esta tendência.

\section{ADITIVOS ANTIOXIDANTES}

Atingir uma elevada fixação de carbono na etapa de queima é um importante objetivo no processamento do refratário, mas não é condição suficiente para garantir o seu desempenho e a sua durabilidade. Para preservar as suas propriedades e assim obter uma vida útil estendida, ainda é necessário assegurar que os mecanismos de degradação atuantes em suas condições de serviço não removam o carbono facilmente. A oxidação é um dos mecanismos de degradação mais presentes e também um dos mais difíceis de ser barrado, sendo ainda mais preocupante no caso do carbono não grafítico derivado de fontes como as resinas termofixas, uma vez que ele já é naturalmente mais reativo que o grafite. Entre os meios encontrados para amenizar os processos de oxidação, o uso dos chamados aditivos antioxidantes ganha destaque pela eficácia e também pelos demais benefícios que essas substâncias podem acabar proporcionando ao refratário. Adicionados à composição refratária usualmente em teores de apenas 3 a $5 \%$ p, esses aditivos conseguem reduzir a susceptibilidade do carbono à oxidação por meio de uma grande diversidade de mecanismos $[9,51]$ : reagindo com o CO da atmosfera de forma a recuperar o carbono sólido; reagindo diretamente com o carbono para a formação de carbetos, os quais são mais resistentes à oxidação que o próprio carbono; reduzindo a porosidade do refratário em decorrência das reações que levam a produtos com maior volume específico e/ou que se depositam em meio aos poros; formando fases líquidas que bloqueiam a porosidade e/ou recobrem a superfície do carbono; formando uma camada protetora sobre a superfície quente do refratário; formando compostos que beneficiam a resistência mecânica e a resistência à corrosão (como whiskers de $\mathrm{AlN}$ e $\mathrm{SiC}$, e $\mathrm{MgAl}_{2} \mathrm{O}_{4}$ ); e reduzindo a pressão de oxigênio na interface em que ocorrem as reações de oxidação.

Os pós metálicos, os carbetos e os boretos destacamse como os principais grupos de antioxidantes aplicados aos refratários contendo carbono. Como cada substância apresenta suas peculiaridades, a escolha do antioxidante mais adequado deve ser feita com base na análise de fatores como a composição do refratário e as condições de serviço a que este estará sendo submetido. É muito comum o uso combinado de dois ou até mesmo três tipos de antioxidantes diferentes, sendo tal opção vantajosa, uma vez que cada um pode atuar de formas e em faixas de temperatura distintas, promovendo assim uma proteção mais completa para o revestimento $[9,51]$. O alumínio, o magnésio e o silício são os metais mais aplicados na função de antioxidante, possuindo como principais vantagens os seus custos relativamente baixos e a capacidade de beneficiarem, além da resistência à oxidação, também a resistência mecânica e a resistência à erosão do refratário [5, 9, 18, 51]. A combinação desses metais na forma de ligas é ainda mais benéfica em comparação a quando são usados isoladamente. No entanto, a atuação dos pós metálicos pode ser comprometida pela facilidade com que eles são hidratados, desfavorecendo assim a sua aplicação em composições refratárias que contenham água (como em concretos, por exemplo). Diversas técnicas para recobrir esses pós com uma camada protetora contra a hidratação têm sido desenvolvidas, mas até o momento nenhuma conseguiu ser completamente eficaz [51]. No caso do alumínio metálico, a presença da umidade mais uma vez se torna problemática com a formação da fase $\mathrm{Al}_{4} \mathrm{C}_{3}$, pois esse carbeto também é susceptível à hidratação e, nesse processo, sofre significativas expansões volumétricas que podem acabar gerando trincas no refratário. Contudo, esse inconveniente pode ser reduzido pela combinação do alumínio com carbetos de outros metais, levando assim à formação de compostos mais complexos, como o $\mathrm{Al}_{8} \mathrm{~B}_{4} \mathrm{C}_{7} \mathrm{e}$ $\mathrm{Al}_{4} \mathrm{SiC}_{4}$, que são mais resistentes à hidratação e ainda atuam como antioxidantes [51]. O uso do alumínio também deve ser analisado com cautela no caso de refratários de $\mathrm{MgO}-\mathrm{C}$ que ficarão em contato com escórias ácidas. Para esses refratários, o alumínio atua formando uma camada densa de $\mathrm{MgO}$ na superfície externa do revestimento, a qual deveria proteger o carbono contra a oxidação. Porém, à medida que o alumínio se oxida e enriquece a escória ácida em $\mathrm{Al}_{2} \mathrm{O}_{3}$, o limite de solubilidade do $\mathrm{MgO}$ nesta vai aumentando, acelerando assim a dissolução da camada densa de $\mathrm{MgO}$ que havia se formado e, portanto, diminuindo o efeito positivo da adição do alumínio [9].

Os principais carbetos antioxidantes são o carbeto de silício $(\mathrm{SiC})$ e o de boro $\left(\mathrm{B}_{4} \mathrm{C}\right)$. $\mathrm{Na}$ verdade, o carbeto de silício atua por mecanismos similares aos do silício metálico, mas acaba não sendo tão eficiente quanto ele por formar menores quantidades da fase $\mathrm{Mg}_{2} \mathrm{SiO}_{4}$, a qual teria a função de reduzir a porosidade do refratário para evitar a penetração do oxigênio e da escória [51]. Por outro lado, o $\mathrm{SiC}$ teria a vantagem de não ser susceptível à hidratação como o pó metálico, o que facilitaria a sua aplicação e garantiria que todo o aditivo adicionado estaria disponível para atuar na proteção do refratário. Já o carbeto de boro previne a oxidação ao reagir com o oxigênio no lugar do carbono e ao recuperar o carbono sólido pela redução do $\mathrm{CO}$ gasoso. Essas duas reações também acabam levando à formação de uma densa camada de $\mathrm{B}_{2} \mathrm{O}_{3}$ sobre a superfície quente do refratário, protegendo-o assim do contato com a atmosfera oxidante $[9,51]$. $\mathrm{O} \mathrm{B}_{2} \mathrm{O}_{3}$ e outros compostos formados pelo boro (como os boretos $\mathrm{ZrB}_{2}, \mathrm{MgB}$ e $\mathrm{CaB}_{6}$ ) fundem já a baixas temperaturas, e assim acabam dando origem a fases líquidas que também podem agir contra a oxidação ao bloquearem a porosidade do refratário. Porém, além desses antioxidantes a base de boro serem caros, essas fases líquidas que eles formam acabam por prejudicar a 
resistência mecânica e a resistência à corrosão dos refratários que são submetidos a temperaturas de serviço mais elevadas $[9,51]$. Contudo, diversos estudos têm comprovado que as combinações entre antioxidantes metálicos e os compostos por boro geralmente levam tanto aos melhores resultados de resistência à oxidação como também de resistência à corrosão por escórias. Como exemplos dessas combinações é possível citar o $\mathrm{Al}+\mathrm{B}_{4} \mathrm{C}$ [51] e o $\mathrm{Al}+\mathrm{ZrB}_{2}$ [9]. Além da composição química, a granulometria do aditivo antioxidante também tem efeitos significativos sobre o seu desempenho, um comportamento que já seria esperado em vista da sempre presente relação entre área superficial específica e reatividade. Alguns trabalhos já teriam comprovado, por exemplo, que a eficiência do alumínio em pó aumenta com a redução de sua granulometria [9]. Já Luz e Pandolfelli [51] destacam entre as tendências das pesquisas sobre esses aditivos o crescente interesse pelos antioxidantes com tamanho de partícula nanométrico.

\section{ADITIVOS PARA FORMAÇÃO DE FASES ESPECIAIS}

Além da composição química e da estrutura cristalina, uma terceira variável que vem merecendo atenção crescente nos últimos anos para o planejamento da microestrutura dos refratários contendo carbono é a morfologia das fases que os compõem. O grande impacto da morfologia das fases sobre as propriedades dos materiais já é um comportamento bem conhecido e empregado na ciência e na indústria dos compósitos, assim como também no desenvolvimento de algumas cerâmicas técnicas. Já no campo das cerâmicas refratárias estruturais, o aproveitamento do real potencial que há por trás do controle da morfologia ainda aparenta estar em seus primeiros passos, mesmo em nível de pesquisa. Porém, para o caso dos refratários contendo carbono, talvez essa situação comece a se modificar em conseqüência dos resultados muito positivos de uma série de trabalhos que vêm sendo publicados desde 2005 pelos grupos de pesquisa ligados ao pesquisador C. Aneziris. Tais trabalhos, entre outras descobertas, têm comprovado que o desenvolvimento "in-situ" de fases em formato de whiskers pode trazer grandes benefícios não apenas às propriedades mecânicas, como também à resistência à oxidação de importantes famílias de refratários contendo carbono. Apresentando assim efeitos tão significativos, esses whiskers prometem alterar sensivelmente a ordem de prioridade das características desejadas a essas cerâmicas. Entretanto, esses whiskers estudados por Aneziris não envolvem apenas os de morfologia acicular (em formato de agulha), já tão conhecidos nos dias atuais, mas principalmente os chamados whiskers "dumbbell-shaped" (em tradução para o português, whiskers em formato de halteres). Essa diferença é muito relevante, visto que já existem tanto resultados laboratoriais como modelos teóricos que comprovam a superioridade do formato "dumbbell-shaped" sobre o acicular em relação ao nível do benefício conferido às propriedades de materiais compósitos [52]. Pelos exemplos dados na Fig. 3, é possível observar as diferenças existentes essas duas estruturas.

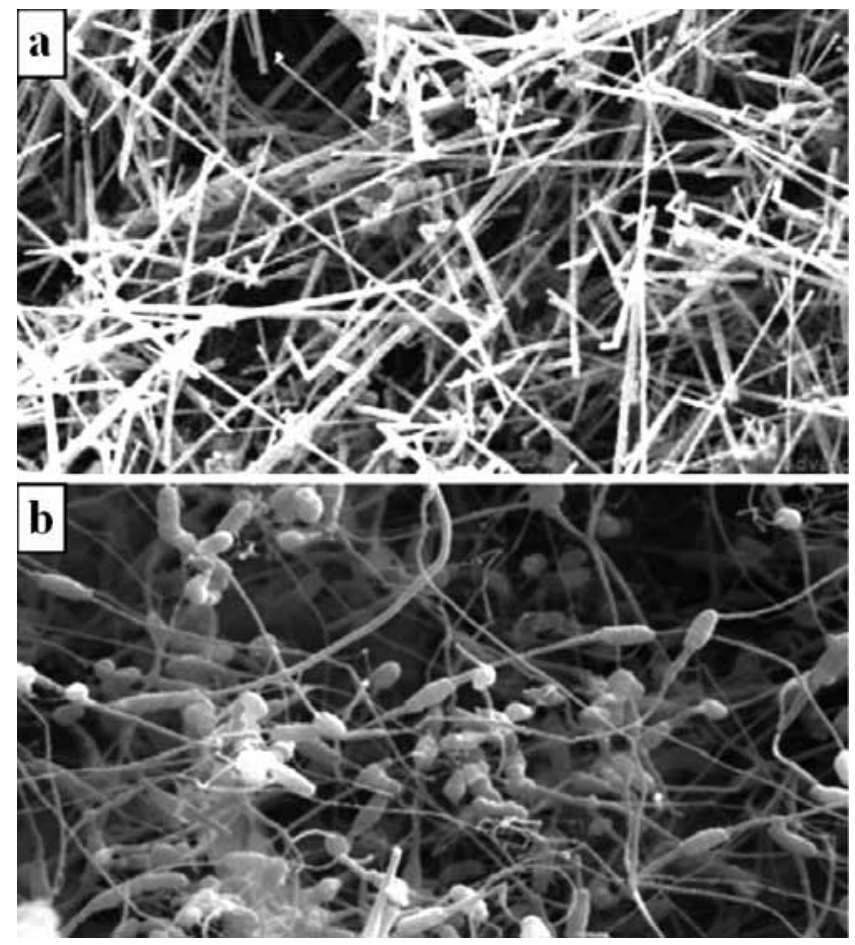

Figura 3: Diferentes morfologias de whiskers: (a) whiskers aciculares [53], (b) whiskers "dumbbell-shaped" [36].

[Figure 3: Different whiskers morphologies: (a) needle-like whiskers [53], (b) dumbbell-shaped whiskers [36].]

Também é interessante salientar que esses whiskers especiais não surgem do desenvolvimento de uma única fase cerâmica. Nos trabalhos publicados pelos grupos de Aneziris, que são discutidos a seguir, é possível verificar que uma grande diversidade de fases pode gerar tais estruturas, principalmente carbetos. Além dos whiskers, outras morfologias que também beneficiariam o desempenho dos refratários contendo carbono serão apresentadas e discutidas.

\subsection{Whiskers de $\mathrm{\beta}-\mathrm{SiC}$ nos Sistemas $\mathrm{Al}_{2} \mathrm{O}_{3}-\mathrm{C}$ e $\mathrm{Al}_{2} \mathrm{O}_{3}-$ $\mathrm{ZrO}_{2}-\mathrm{C}$}

Como foi mencionado no capítulo anterior, a eficácia do silício metálico como antioxidante e seus benefícios às propriedades mecânicas do refratário devido à formação "in-situ" de whiskers de SiC já são bem conhecidos e aplicados na pesquisa e na indústria de refratários. Porém, a importância da morfologia desses whiskers e de outras estruturas formadas pelo silício parece ter vindo à tona apenas em 2005, com a publicação dos resultados do trabalho desenvolvido por Aneziris e pelo grupo de pesquisadores Y. $\mathrm{Li}, \mathrm{X}$. Yi, S. Jin e N. Li, que revelou a presença de whiskers "dumbbell-shaped" de $\beta$-SiC nos sistemas refratários $\mathrm{Al}_{2} \mathrm{O}_{3}-\mathrm{C}$ e $\mathrm{Al}_{2} \mathrm{O}_{3}-\mathrm{ZrO}_{2}-\mathrm{C}$ [52]. Os autores puderam avaliar a formação e evolução desses whiskers através da análise de duas composições, às quais foram adicionadas $18 \%$ p (para o sistema $\mathrm{Al}_{2} \mathrm{O}_{3}-\mathrm{C}$ ) e $7 \%$ p (para o sistema $\mathrm{Al}_{2} \mathrm{O}_{3}-\mathrm{ZrO}_{2}-\mathrm{C}$ ) de silício metálico em pó com uma granulometria de 200 
mesh. Ambas utilizaram como fontes de carbono "flakes" de grafite e negro de fumo. No caso sistema $\mathrm{Al}_{2} \mathrm{O}_{3}-\mathrm{C}$, também é citado o uso de uma resina fenólica novolaca para atuar na função de ligante. Já na descrição do sistema $\mathrm{Al}_{2} \mathrm{O}_{3}$ $\mathrm{ZrO}_{2}-\mathrm{C}$ não se mencionou a adição de qualquer ligante, $\mathrm{o}$ que leva a subentender que a mesma resina teria sido usada. Com a queima das amostras de $\mathrm{Al}_{2} \mathrm{O}_{3}-\mathrm{C}$ a temperaturas entre 1200 e $1600{ }^{\circ} \mathrm{C}$, e com a análise das mesmas por meio de difração de raios-X e por imagens de microscopia eletrônica de varredura, pode-se observar a contínua transformação das fases contendo silício. Logo na queima a $1200{ }^{\circ} \mathrm{C}$, o silício metálico já proporcionou o surgimento de whiskers de $\beta$-SiC com diâmetros de dimensões nanométricas, tanto no formato acicular como "dumbbell-shaped", além de estruturas esferoidais que foram identificadas como sendo a fase cristobalita. Porém, para temperaturas de sinterização superiores, o desaparecimento da cristobalita indica que, assim como o próprio silício metálico, esta fase também estaria sendo consumida para a formação dos whiskers. De acordo com os autores, $1200{ }^{\circ} \mathrm{C}$ realmente seria a temperatura mínima necessária para a formação dos whiskers "dumbbell-shaped". Com a queima a $1300{ }^{\circ} \mathrm{C}$, a quantidade de whiskers "dumbbell-shaped" nanométricos atingiu seu nível máximo e, estando distribuídos uniformemente pela matriz das amostras (juntamente com os whiskers em agulha e as esferas de cristobalita), eles acabaram por formar uma espécie de rede ou malha em meio à estrutura do refratário. Essa rede de whiskers também é formada com a queima das amostras a $1400{ }^{\circ} \mathrm{C}$, enquanto o tratamento a $1500{ }^{\circ} \mathrm{C}$ já começa a proporcionar uma microestrutura mais grosseira, com os whiskers atingindo dimensões micrométricas em seus diâmetros e apresentando uma distribuição menos uniforme pela fase matriz. Segundo as informações apresentadas, compreendeu-se que a explicação para tal evolução da microestrutura do refratário estaria no aumento da reatividade do $\mathrm{SiO}_{(\mathrm{g})}$ com a elevação da temperatura de queima, sendo este um composto gasoso formado a partir da oxidação do pó de silício. Tornando-se mais reativo, a difusão homogênea desse gás pela microestrutura passaria a ser dificultada, levando então ao aumento do diâmetro dos whiskers e concentrando a formação destes em pontos mais isolados (ou seja, a malha de whiskers não seria mais uniforme). Além disso, a maior reatividade dificultaria a deposição do $\mathrm{SiO}_{(\mathrm{g})}$ sobre as falhas de empilhamento dos whiskers de $\mathrm{SiC}$ constituídos previamente, sendo que este processo de deposição seria o responsável pela formação das estruturas esféricas que compõem os whiskers "dumbbellshaped", as quais são denominadas pelos autores como "beads" (ou seja, os whiskers "dumbbell-shaped" seriam construídos a partir dos whiskers aciculares [54]). Inclusive, a análise desses "beads" por fluorescência de raios X mostrou o predomínio dos elementos silício e oxigênio em sua composição, enquanto o exame por difração de elétrons determinou tais estruturas como sendo amorfas.

Passando-se agora aos resultados obtidos para o sistema $\mathrm{Al}_{2} \mathrm{O}_{3}-\mathrm{ZrO}_{2}-\mathrm{C}$, as amostras deste foram submetidas a ensaios de resistência à flexão a frio, pelos quais foi possível observar que as melhores propriedades foram atingidas pelas amostras tratadas a 1300 e $1400{ }^{\circ} \mathrm{C}$. Ou seja, nas mesmas temperaturas de queima em que se havia observado a formação da rede de whiskers no sistema $\mathrm{Al}_{2} \mathrm{O}_{3}-\mathrm{C}$, o que sugere que tal microestrutura seja a responsável pelo avanço das propriedades mecânicas. Considerando, por exemplo, o comportamento do módulo de ruptura a frio, este passou de aproximadamente $30 \mathrm{MPa}$, entre as amostras de $\mathrm{Al}_{2} \mathrm{O}_{3}$ $\mathrm{ZrO}_{2}-\mathrm{C}$ queimadas a $1200{ }^{\circ} \mathrm{C}$, para mais de $40 \mathrm{MPa}$ com a queima a $1400{ }^{\circ} \mathrm{C}$, o que significa um ganho de resistência de quase $35 \%$. Em um segundo trabalho sobre esse sistema refratário, Aneziris et al [55] inovam ao complementá-lo não apenas com silício metálico, mas também com alumínio e titânia $\left(\mathrm{TiO}_{2}\right)$ em pó (inovação que gerou a patente [56]). A descrição das composições desenvolvidas, variando a combinação desses aditivos, é apresentada na Tabela IV. As amostras foram preparadas por prensagem e queimadas a 1100 e $1350{ }^{\circ} \mathrm{C}$, sendo avaliadas quanto à resistência mecânica à compressão (a frio), antes e depois da aplicação de cinco ciclos de choque térmico (realizado a $1000{ }^{\circ} \mathrm{C}$ e com resfriamento por ar comprimido).

Os resultados desses ensaios são apresentados na Fig. 4, pela qual se verifica a grande superioridade da composição A (que combina os três aditivos) tanto entre as amostras queimadas a 1100 como a $1350{ }^{\circ} \mathrm{C}$. Ela se mantém como a mais resistente mesmo após a aplicação dos choques térmicos, enquanto as demais composições sofrem quedas de resistência que, na maioria das vezes, ultrapassam os $30 \%$. Para as amostras tratadas a $1350{ }^{\circ} \mathrm{C}$ os resultados se apresentam ainda mais interessantes, pois a composição A, ao invés de apresentar a esperada piora de suas propriedades, acaba tendo sua resistência elevada em mais de $20 \%$ após os cinco ciclos de choque térmico de $950{ }^{\circ} \mathrm{C}$. Ou seja, as solicitações térmicas a teriam fortalecido. Os autores atribuem tal comportamento incomum às fases que surgem na composição $\mathrm{A}$ com o tratamento a $1350{ }^{\circ} \mathrm{C}$, que são novamente os whiskers "dumbbell-shaped" de $\beta$-SiC, mais o SiAlON, alumina condensada, sílica, $\mathrm{Al}_{4} \mathrm{C}_{3}$ e a fase $\mathrm{Ti}\left(\mathrm{C}_{1-\mathrm{x}} \mathrm{N}_{\mathrm{x}}\right)$. Essa última apresentaria uma morfologia similar a de tecidos como o feltro (originando o termo "felt-like $\operatorname{Ti}\left(\mathrm{C}_{1-\mathrm{x}} \mathrm{N}_{\mathrm{x}}\right.$ )") e em escala nanométrica. Estando bem distribuída pela matriz, essa fase acabaria atuando como um reforço para a mesma.

Contudo, não é revelado o que exatamente ocorreria com essas seis fases durante a solicitação de choque térmico para que elas causassem o aumento da resistência mecânica da composição A. Não se poderia afirmar com certeza, por exemplo, que isso seria uma conseqüência dos choques térmicos representarem um incentivo para formação dessas fases, o que então intensificaria o reforço do refratário. Portanto, ainda seria necessário compreender os mecanismos por trás deste resultado. Uma ressalva interessante feita pelos autores para as vantagens da adição do silício em pó ao sistema $\mathrm{Al}_{2} \mathrm{O}_{3}-\mathrm{ZrO}_{2}-\mathrm{C}$, ou mesmo a outros refratários, seria o problema da contaminação do aço por esse metal, já que a formação dos whiskers pode não consumir o silício completamente. Por essa razão, eles propõem que os whiskers de $\beta$-SiC sejam pré-fabricados e 
Tabela IV - Composições do sistema $\mathrm{Al}_{2} \mathrm{O}_{3}-\mathrm{ZrO}_{2}$-C usando cinco combinações de aditivos [55]. [Table IV - Compositions of the $\mathrm{Al}_{2} \mathrm{O}_{3}-\mathrm{ZrO}_{2}-\mathrm{C}$ system with five combinations of additives [55].]

\begin{tabular}{rcccccc}
\hline & & \multicolumn{5}{c}{ Composições (\%p) } \\
Matéria-primas & Granulometria & $\mathrm{A}$ & $\mathrm{B}$ & $\mathrm{C}$ & $\mathrm{D}$ & $\mathrm{E}$ \\
\hline & $8-14$ mesh & 30,0 & 30,0 & 30,0 & 30,0 & 30,0 \\
Alumina & $14-28$ mesh & 10,0 & 10,0 & 10,0 & 10,0 & 10,0 \\
& $<28$ mesh & 15,0 & 15,0 & 15,0 & 15,0 & 15,0 \\
Córindon branco & $<5 \mu \mathrm{m}$ & 10,0 & 10,0 & 10,0 & 10,0 & 10,0 \\
Alumina-zircônia & $14-28$ mesh & 10,0 & 10,0 & 10,0 & 10,0 & 10,0 \\
fundida (73\%p Al $\mathrm{O}_{3}$, & $<28$ mesh & 5,0 & 5,0 & 5,0 & 5,0 & 5,0 \\
$26,5 \%$ p ZrO $\left.{ }_{2}\right)$ & $<325$ mesh & 5,0 & 5,0 & 5,0 & 5,0 & 5,0 \\
Alumina calcinada & - & 3,1 & 5,6 & 6,1 & 8,6 & 3,5 \\
"Flakes" de grafite & $<200$ mesh & 5,0 & 5,0 & 5,0 & 5,0 & 5,0 \\
Negro de fumo & - & 1,0 & 1,0 & 1,0 & 1,0 & 1,0 \\
Silício & $<200$ mesh & 3,0 & 3,0 & - & - & 3,0 \\
Alumínio & $<200$ mesh & 2,5 & - & 2,5 & - & 2,5 \\
Titânia & $\mathrm{d}_{50}=1,5 \mu \mathrm{m}$ & 0,4 & 0,4 & 0,4 & 0,4 & - \\
& & $100 \%$ & $100 \%$ & $100 \%$ & $100 \%$ & $100 \%$ \\
\hline Ligante: resina fenólica novolaca & 4,0 & 4,0 & 4,0 & 4,0 & 4,0 \\
\hline
\end{tabular}
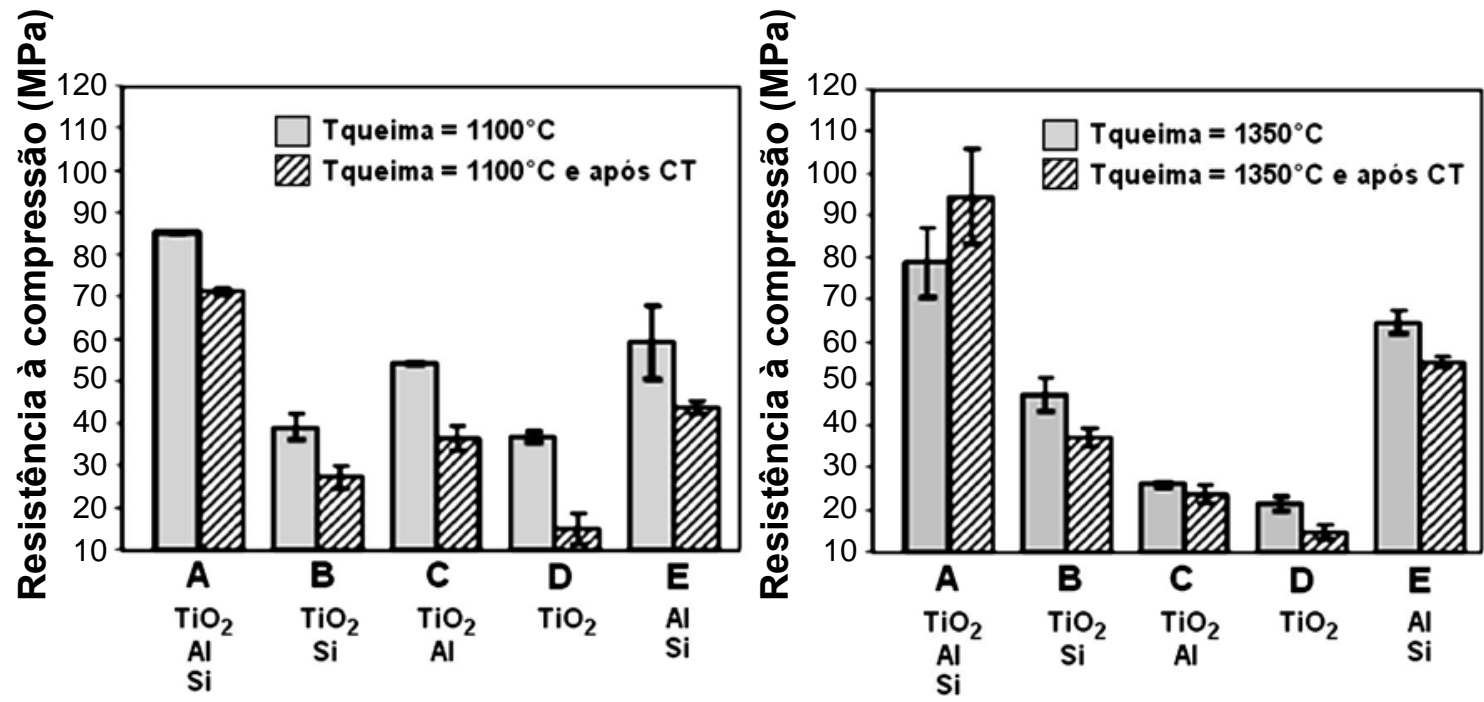

Figura 4: Resistência à compressão das composições queimadas a 1100 e $1350{ }^{\circ} \mathrm{C}$, antes e após cinco ciclos de choque térmico (CT) de $950{ }^{\circ} \mathrm{C}[55]$.

[Figure 4: Compression strength of compositions fired at 1100 and $1350^{\circ} \mathrm{C}$, before and after five thermal shock cycles (CT) of $\left.950^{\circ} \mathrm{C}[55].\right]$

depois incorporados à composição refratária definitiva. No entanto, tal processo seria obviamente mais trabalhoso e caro. Duas questões que surgem aqui, e que também devem ser levantadas para os outros carbetos que constituem os whiskers "dumbbell-shaped", são sobre qual ou quais seriam as fontes de carbono que participam das reações responsáveis por sintetizá-los, e se haveria uma fonte de carbono mais favorável para a formação desses whiskers. Pela sua estrutura mais defeituosa e, portanto, mais reativa, esta se supondo que o carbono fornecido pelas resinas fenólicas provavelmente seria um dos mais participativos nessas reações.

\subsection{Whiskers de $\mathrm{Al}_{2} \mathrm{OC}, \mathrm{Al}_{4} \mathrm{O}_{4} \mathrm{C}$ e $\mathrm{Al}_{4} \mathrm{C}_{3}$ no sistema $\mathrm{MgO}-\mathrm{C}$}

Tal como o silício, o alumínio em pó também é um dos agentes antioxidantes mais convencionais na indústria refratarista. No entanto, em três trabalhos dos anos de 2006 e 2007, Aneziris et al [31, 36, 55] demonstram que adições de titânia e, principalmente, de combinações de 
alumínio metálico com titânia, podem superar em muito tanto o efeito antioxidante como também o benefício às propriedades mecânicas que o alumínio seria capaz de proporcionar quando aplicado isoladamente. De fato, o $\mathrm{TiO}_{2}$ também é reconhecido por sua ação antioxidante, embora o seu uso para tal finalidade não seja tão disseminado quanto o do alumínio. Assim como outros óxidos antioxidantes, o mecanismo de ação do $\mathrm{TiO}_{2}$ estaria baseado na sua capacidade de doar elétrons ao grafite, proporcionando a ele uma distribuição eletrônica mais estável que aumentaria sua resistência ao ataque do oxigênio [31,51]. No entanto, de acordo com os resultados obtidos por Aneziris at al, os benefícios do uso da titânia não seriam devidos a esse mecanismo. O sistema refratário utilizado para analisar as conseqüências do uso da titânia e do alumínio metálico consistiu em uma composição de tijolos de $\mathrm{MgO}-\mathrm{C}$ contendo como fontes de carbono o grafite em "flakes" e um sistema ligante constituído por $2,1 \%$ p de uma resina novolaca líquida e cerca de $1,0 \%$ p da resina carbonácea Carbores ${ }^{\circledR}$ P. A essa composição básica foram acrescentados, tanto isoladamente como combinados, $0,4 \%$ p de $\mathrm{TiO}_{2}$ (como um pó de granulometria nanométrica) e $2,4 \%$ p de $\mathrm{Al}$ (como um pó com granulometria micrométrica), resultando assim nas quatro composições descritas pela Tabela V.

Essas composições foram conformadas por prensagem, curadas a $180^{\circ} \mathrm{C}$ e queimadas a $1000^{\circ} \mathrm{C}[31] \mathrm{e} 1500^{\circ} \mathrm{C}[36,55]$. Suas amostras foram avaliadas quanto à porosidade, resistência à oxidação $\left(\mathrm{a} 1200^{\circ} \mathrm{C}\right)$ e quanto às propriedades mecânicas a frio, isso tanto por meio de ensaios de resistência à compressão (em [31]) como por ensaios de resistência à flexão a três pontos (em [36, 55]). Para analisar o desenvolvimento da microestrutura em função da temperatura de queima, outras amostras dessas composições foram preparadas sem a adição das frações agregadas grosseiras (ou seja, os "flakes" de grafite e os agregados $\mathrm{MgO}$ ). Essas composições, denominadas pelos autores como composições modelo, foram queimadas em cadinhos a 1000,1300 e $1500{ }^{\circ} \mathrm{C}$ (em meio a uma atmosfera não controlada, mas recobertos por carbono em pó), sendo em seguida analisadas pelas técnicas de difração de raios $\mathrm{X}$, difração de elétrons retroespalhados, fluorescência de raios X por dispersão de energia e microscopia eletrônica de varredura. A análise da evolução da microestrutura é apresentada de forma completa na referência [31], sendo suas principais observações e conclusões destacadas a seguir.

Para a composição modelo aditivada apenas com o alumínio metálico e tratada a $1000{ }^{\circ} \mathrm{C}$, os autores puderam observar a formação de whiskers cristalinos das fases $\mathrm{Al}_{4} \mathrm{C}_{3}$ e $\mathrm{Al}_{2} \mathrm{OC}$, possuindo esses a morfologia convencional acicular. No entanto, tais whiskers cristalinos dão lugar a whiskers amorfos com a elevação da temperatura de queima para $1300{ }^{\circ} \mathrm{C}$. Já na composição aditivada apenas com $\mathrm{TiO}_{2}$, ocorre a formação da fase cristalina TiCN cúbica para temperaturas a partir de $1200{ }^{\circ} \mathrm{C}$. Nisso, a vantagem do $\mathrm{TiO}_{2}$ sobre o $\mathrm{Al}$ na função de antioxidante parece se revelar, pois os resultados dos ensaios de resistência à oxidação, apresentados pela Tabela VI, indicam que essa composição alcançou um desempenho significativamente superior ao daquela em que apenas o alumínio em pó foi adicionado. Portanto, a fase TiCN seria mais eficiente que os whiskers amorfos para dificultar oxidação, comportamento que os autores parecem sugerir ser devido à forte adesão que essa fase gera entre os grãos de $\mathrm{MgO}$ e a matriz, o que então reduziria a permeabilidade da estrutura aos gases oxidantes e ainda proporcionaria algum incremento nas propriedades mecânicas.

Com a combinação do alumínio e da titânia, novamente se observa nas amostras tratadas a $1000{ }^{\circ} \mathrm{C}$ o surgimento de whiskers das fases $\mathrm{Al}_{4} \mathrm{C}_{3}$ e $\mathrm{Al}_{2} \mathrm{OC}$ (e depois também da fase $\mathrm{Al}_{4} \mathrm{O}_{4} \mathrm{C}, \mathrm{a} 1300{ }^{\circ} \mathrm{C}$ ). Porém, agora esses whiskers se mantêm cristalinos mesmo com a elevação do tratamento térmico a $1500{ }^{\circ} \mathrm{C}$ e, além disso, passam a apresentar a morfologia "dumbbell-shaped", como se pode verificar pela Fig. 5. Essas estruturas esclareceriam a resistência mecânica em média $30 \%$ superior apresentada por esta composição em relação às demais (Tabela VI). Assim como explicado anteriormente para o caso da fase $\beta$-SiC, os whiskers desses carbetos e oxicarbetos de alumínio se organizariam como uma malha pela matriz do refratário, conferindo a este maior flexibilidade, resistência mecânica, além de uma estrutura mais densa. Esse último ganho somado à maior resistência desses whiskers cristalinos à oxidação (em comparação aos amorfos) e à formação da fase TiC cúbica (cujo comportamento seria semelhante ao da fase TiCN quanto à adesão que promove entre a matriz e os agregados) teriam sido os responsáveis pelo elevado desempenho dessa composição nos ensaios de resistência à oxidação, como indica a Tabela VI.

Adicionalmente, os autores também concluem que a maior adesão produzida pelas fases $\mathrm{TiCN}$ e $\mathrm{TiC}$ entre a fase matriz e os agregados seria a responsável pela maior resistência à abrasão observada nas duas composições aditivadas com $\mathrm{TiO}_{2}$. Assim, de acordo com a referência [31], organizou-se a Tabela VII com as principais fases formadas e suas morfologias, em função dos aditivos e das temperaturas de queima das composições modelo do sistema MgO-C. Nas referências [36] e [55], os autores freqüentemente retomam essa análise da evolução das fases para explicar outros resultados obtidos. Contudo, alguns comentários feitos nestas referências vão muitas vezes contra o que havia sido apresentado ou compreendido em [31].

Enquanto em [31] os autores sugerem que a fase TiCN teria surgido a temperaturas acima de $1200^{\circ} \mathrm{C}$ (temperatura do ensaio de resistência à oxidação) e os resultados da difração de raios $\mathrm{X}$ deixam claro que ela teria se formado apenas na composição aditivada com $\mathrm{TiO}_{2}$, em [36], Aneziris e Klippel comentam que a fase TiCN já se formaria a $1000^{\circ} \mathrm{C}$ e também na composição que combina $\mathrm{Al}$ e $\mathrm{TiO}_{2}$. Em [31] também se dá a entender que os whiskers "dumbbel-shaped" $\mathrm{de}_{4} \mathrm{Cl}_{3} \mathrm{e}$ $\mathrm{Al}_{2} \mathrm{OC}$ já teriam sido formados a $1000^{\circ} \mathrm{C}$, já que os autores discutem sua interferência nas propriedades mecânicas com base nos resultados de resistência à compressão de amostras tratadas a essa temperatura. No entanto, comenta-se em [36] que os whiskers "dumbbell-shaped" da fase $\mathrm{Al}_{4} \mathrm{C}_{3}$ se 
Tabela V - Variações da composição do sistema MgO-C avaliadas por Aneziris et al $[31,36,55]$.

[Table $V$-Variations of the MgO-C system compositions evaluated by Aneziris et al [31, 36, 55].]

\begin{tabular}{|c|c|c|c|c|}
\hline \multirow[b]{2}{*}{ Matérias-primas (\%p) } & \multicolumn{4}{|c|}{ Composições } \\
\hline & $\begin{array}{c}\text { Isenta de } \\
\text { aditivos }\end{array}$ & $+\mathrm{Al}$ & $+\mathrm{TiO}_{2}$ & $+\left(\mathrm{Al}+\mathrm{TiO}_{2}\right)$ \\
\hline $\mathrm{MgO}(2-4 \mathrm{~mm})$ & 19,8 & 19,4 & 19,5 & 19,0 \\
\hline $\mathrm{MgO}(1-2 \mathrm{~mm})$ & 31,4 & 30,7 & 31,4 & 30,6 \\
\hline $\mathrm{MgO}(0-1 \mathrm{~mm})$ & 21,3 & 20,8 & 21,2 & 20,7 \\
\hline $\mathrm{MgO}$ em pó & 12,6 & 12,3 & 12,7 & 12,4 \\
\hline Grafite $\left(1 \mathrm{~m}^{2} / \mathrm{g}\right)$ & 11,6 & 11,3 & 11,6 & 11,3 \\
\hline Novolaca líquida & 2,1 & 2,1 & 2,1 & 2,1 \\
\hline HMTA & 0,2 & 0,2 & 0,2 & 0,2 \\
\hline Carbores $^{\circledR} \mathrm{P}$ & 1,0 & 0,9 & 1,0 & 0,9 \\
\hline $\mathrm{TiO}_{2}$ em pó $(<1 \mu \mathrm{m})$ & - & - & 0,4 & 0,4 \\
\hline $\mathrm{Al}$ em pó (45 a $75 \mu \mathrm{m})$ & - & 2,4 & - & 2,4 \\
\hline
\end{tabular}

formariam a $1500{ }^{\circ} \mathrm{C}$, e os whiskers dos oxicarbetos teriam a morfologia acicular com a queima a $1000^{\circ} \mathrm{C}$. Já em [55], esses mesmos cometários são feitos, e inclusive se afirma claramente nas conclusões que não houve a formação de whiskers "dumbbell-shaped" nas amostras aditivadas com $\mathrm{TiO}_{2}$ e $\mathrm{Al}$ e queimadas a $1000{ }^{\circ} \mathrm{C}$, sendo que eles surgiriam apenas a $1300{ }^{\circ} \mathrm{C}$, a partir da metamorfose dos whiskers aciculares. Apesar dessas controvérsias quanto à evolução das fases, o comportamento que sempre fica evidente é que o uso da titânia em combinação com o alumínio proporciona a estabilização dos whiskers cristalinos de carbetos e oxicarbetos a altas temperaturas, permite a estes desenvolver a morfologia "dumbbell-shaped", e ainda suporta o desenvolvimento das fases TiC e TiCN. Os resultados das propriedades mecânicas, que são mostrados a seguir, comprovam como todo esse grupo de fases resulta em benefícios para o refratário.

Nas Tabelas VIII e IX podem ser analisados os dois conjuntos de resultados de porosidade e dos ensaios de flexão a três pontos que foram apresentados pelas referências [36] e [55], respectivamente. Optou-se por exibir ambos, pois se verifica que eles são complementares com em respeito a algumas composições. Já outras composições têm seus resultados repetidos, mas esses não se mantiveram totalmente semelhantes de uma referência para outra. Embora algumas dessas diferenças sejam significativas, elas não chegam a afetar completamente as conclusões sobre o efeito dos aditivos e, portanto, serão desconsideradas aqui.
O mesmo ocorre para os resultados de resistência ao choque térmico apresentados nas Tabelas X e XI. Pelos resultados do módulo de ruptura a frio (CMOR), verifica-se que todas as composições aditivadas foram superiores à composição básica, sendo, no mínimo, 25\% mais resistentes. Além disso, as composições que atingem os melhores desempenhos, tanto entre as amostras tratadas a 1000 como a $1500{ }^{\circ} \mathrm{C}$, são justamente as duas para as quais se espera a formação de whiskers (aciculares ou "dumbbell-shaped"), ou seja, as composições aditivadas com $\mathrm{Al}$ e com a combinação $\mathrm{Al}$ $+\mathrm{TiO}_{2}$. E o fato desta última ter alcançado sua resistência máxima a $1500{ }^{\circ} \mathrm{C}$, ultrapassando a tensão de ruptura de todas as demais em mais de $15 \%$, reforçaria a idéia de que os whiskers "dumbbell-shaped" realmente teriam sido formados apenas a temperaturas superiores a $1000^{\circ} \mathrm{C}$, que é uma das controvérsias discutidas anteriormente.

Quanto aos resultados dos ensaios de flexão apresentados nas Tabelas VIII e IX, estes foram utilizados para avaliar o nível de deformação elástica e "plástica" atingível pelas composições quando estas são submetidas a cargas equivalentes a 40 e $80 \%$ de suas tensões de ruptura. Esses resultados incluem o módulo elástico, o deslocamento absoluto da amostra durante o esforço de flexão (flecha) e a porcentagem de deformação "plástica" contida nesse deslocamento. A flecha, segundo os autores, pode ser vista como uma medida da "flexibilidade" do material [36]. Os termos flexibilidade e deformação plástica estão sendo colocados entre aspas apenas para manter as mesmas

Tabela VI - Características e propriedades das composições analisadas em [31].

[Table VI - Characteristics and properties of compositions analyzed in [31].]

\begin{tabular}{cccc}
\hline & \multicolumn{3}{c}{ Composições } \\
Características/Propriedades & $+\mathrm{Al}$ & $+\mathrm{TiO}_{2}$ & $+\left(\mathrm{Al}+\mathrm{TiO}_{2}\right)$ \\
\hline Porosidade aberta $(\% \mathrm{vol})$ & $13,05 \pm 0,05$ & $13,1 \pm 0,05$ & $11,3 \pm 0,05$ \\
Resistência à compressão $(\mathrm{MPa})$ & $22,1 \pm 0,5$ & $23,5 \pm 0,5$ & $32,2 \pm 0,5$ \\
Profundidade de oxidação $(\mathrm{mm})$ & $9 \pm 1$ & $3 \pm 1$ & $2 \pm 1$ \\
\hline
\end{tabular}




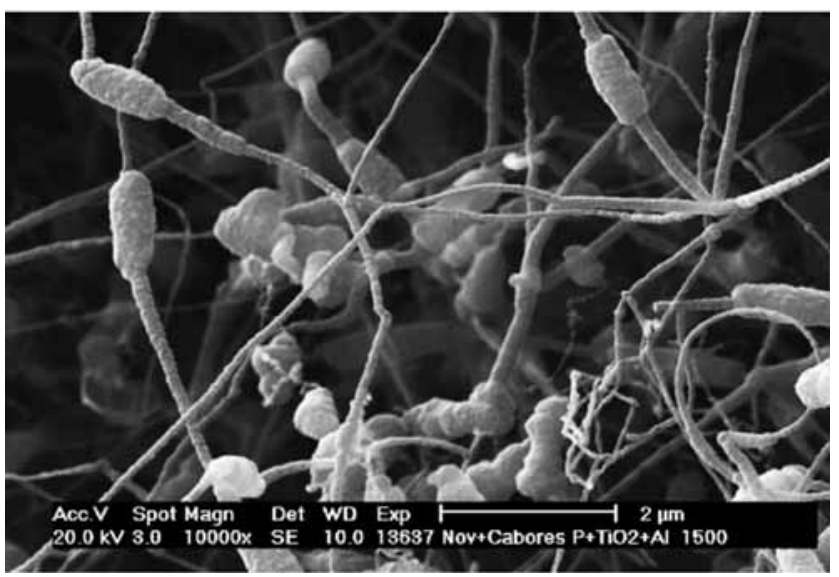

Figura 5: Whiskers "dumbbell-shaped" de $\mathrm{Al}_{2} \mathrm{OC}, \mathrm{Al}_{4} \mathrm{O}_{4} \mathrm{C}$ e $\mathrm{Al}_{4} \mathrm{C}_{3}$

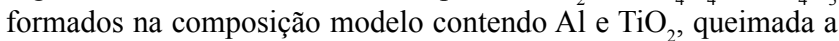
$1500{ }^{\circ} \mathrm{C}[31]$.

[Figure 5: $\mathrm{Al}_{2} \mathrm{OC}, \mathrm{Al}_{4} \mathrm{O}_{4} \mathrm{C}$ and $\mathrm{Al}_{4} \mathrm{C}_{3}$ dumbbell-shaped whiskers generated in the model composition containing $\mathrm{Al}$ and $\mathrm{TiO}{ }_{2}$, fired at $1500{ }^{\circ} \mathrm{C}$ [31].]

expressões utilizadas pelos autores, pois se sabe que os fenômenos de deformação observados a temperatura ambiente devem-se à propagação estável de trincas. Porém, isso não foi esclarecido nesses artigos, o que muitas vezes dificulta sua interpretação. Em [36] e [55], os autores salientam que uma alta capacidade de deformação "plástica" e um módulo elástico relativamente baixo, e que ainda diminua com o aumento da carga aplicada, são fatores positivos para o refratário, pois facilitariam o alívio de tensões térmicas, o que por sua vez se refletiria em uma maior resistência ao choque térmico. Considerando isso e analisando-se os resultados dos ensaios de flexão como um todo, verifica-se que a composição preparada com $\mathrm{Al}$ e $\mathrm{TiO}_{2}$ permaneceria como a mais vantajosa, pois seus resultados se apresentam sempre comparáveis ou superiores aos das demais nos três quesitos quanto a deformabilidade. Assim, nesta composição se uniriam as vantagens da elevada resistência mecânica e da elevada resistência ao choque térmico, o que fica comprovado pelas Tabelas X e XI. Nestas é apresentada a resistência residual das amostras após a primeira (1 CT) e quinta (5 CT) sessões de choque térmico, que foram realizadas com o aquecimento das amostras a 970 ${ }^{\circ} \mathrm{C}$, seguido pelo resfriamento com ar comprimido.

A composição com $\mathrm{Al}$ e $\mathrm{TiO}_{2}$ queimada a $1500{ }^{\circ} \mathrm{C}$ logo se destaca por não sofrer qualquer dano na primeira solicitação térmica, apresentando, aliás, um sutil fortalecimento. Após a quinta solicitação, a sua perda de resistência permanece muito inferior à sofrida pelas demais composições, acabando assim por aumentar ainda mais a distância entre seus desempenhos. Já quando queimada a $1000{ }^{\circ} \mathrm{C}$, repetese o comportamento da perda mínima de resistência com a primeira solicitação (3\%), mas do primeiro para o quinto choque térmico a queda de desempenho $(31 \%)$ já é muito próximo do apresentado pelas outras. De uma forma geral, todas as composições aditivadas foram significativamente superiores à composição de $\mathrm{MgO}-\mathrm{C}$ comum, sendo a única exceção a composição com $\mathrm{TiO}_{2}$ tratada a $1500^{\circ} \mathrm{C}$ que, ao final da aplicação do quinto choque térmico, apresentou praticamente o mesmo valor de resistência que a composição sem aditivos. Esse comportamento pode ser explicado pelo fato das amostras da composição com $\mathrm{TiO}_{2}$, tratadas a $1500{ }^{\circ} \mathrm{C}$, já partirem de um nível de resistência inferior $(2,4$ $\mathrm{MPa})$ em comparação ao das tratadas a $1000^{\circ} \mathrm{C}(2,9 \mathrm{MPa})$, e também pelo efeito antioxidante do $\mathrm{TiO}_{2}$. Segundo Aneziris e Klippel [36], o tratamento a $1500{ }^{\circ} \mathrm{C}$ teria consumido o $\mathrm{TiO}_{2}$ para a formação da fase $\mathrm{TiCN}$, fazendo então com que essa composição perdesse o efeito antioxidante do $\mathrm{TiO}_{2}$, tornando-a assim mais susceptível ao primeiro choque térmico. Porém, como o choque térmico levaria à oxidação parcial do $\mathrm{TiCN}, \mathrm{o} \mathrm{TiO}_{2}$ formado nesse processo passaria depois a proteger a matriz de carbono nos choques térmicos subseqüentes. Isso então explicaria a queda menos brusca da resistência do primeiro para o quinto choque térmico no caso da composição com $\mathrm{TiO}_{2}$ tratada a $1500{ }^{\circ} \mathrm{C}$. No caso das amostras tratadas a $1000^{\circ} \mathrm{C}$, a titânia já estaria presente no material desde o início, reduzindo significativamente o dano causado pelos primeiros choques de temperatura, que é o que se observa na Tabela X.

Portanto, verifica-se que a combinação entre o pó de alumínio e a titânia nanométrica, mesmo quando aplicados em teores tão baixos quanto 2,4 e $0,4 \%$ p, já pode proporcionar ganhos substantivos às propriedades mais importantes dos refratários MgO-C. Isso principalmente se houver condições propícias para a formação de whiskers "dumbbell-shaped" e para que esses fiquem distribuídos uniformemente pela matriz, de modo a criar a microestrutura de malha de whiskers. Adicionalmente, a combinação da titânia com o alumínio ainda contaria com a vantagem de não apresentar o problema do silício quanto à possibilidade de contaminação do aço, como havia sido comentado na seção anterior para o caso dos refratários de $\mathrm{Al}_{2} \mathrm{O}_{3}-\mathrm{ZrO}_{2}-\mathrm{C}$. Contudo, apesar desse inconveniente do silício, acreditase que ainda seria interessante averiguar que resultados

Tabela VII - Principais fases observadas em função da temperatura de queima de acordo com [31].

[Table VII - Main phases observed as a function of firing temperature according to [31].]

\begin{tabular}{|c|c|c|c|}
\hline \multirow[b]{2}{*}{$\mathrm{T}_{\text {queima }}$} & \multicolumn{3}{|c|}{ Composições } \\
\hline & $+\mathrm{Al}$ & $+\mathrm{TiO}_{2}$ & $+\left(\mathrm{Al}+\mathrm{TiO}_{2}\right)$ \\
\hline $1000^{\circ} \mathrm{C}$ & $\mathrm{Al}_{4} \mathrm{C}_{3}$ e $\mathrm{Al}_{2} \mathrm{OC}$ (whiskers em agulha cristalinos) & - & TiC cúbico \\
\hline $1300^{\circ} \mathrm{C}$ & Whiskers em agulha amorfos & TiCN cúbico & $\mathrm{AlC}$ e Al OC (whiskers \\
\hline $1500{ }^{\circ} \mathrm{C}$ & Whiskers em agulha amorfos & TiCN cúbico & cristalinos "dumbbell-shaped") \\
\hline
\end{tabular}


Tabela VIII - Resultados para a porosidade e propriedades mecânicas de acordo com [36].

[Table VIII - Porosity and mechanical properties results according to [36].]

\begin{tabular}{|c|c|c|c|c|c|c|c|c|c|}
\hline \multirow[b]{2}{*}{$\mathrm{T}_{\text {queima }}$} & \multirow[b]{2}{*}{$\begin{array}{c}\text { Características/ } \\
\text { Propriedades }\end{array}$} & \multicolumn{8}{|c|}{ Composições } \\
\hline & & \multicolumn{2}{|c|}{$\begin{array}{l}\text { Isenta de } \\
\text { aditivos }\end{array}$} & \multicolumn{2}{|c|}{$+\mathrm{Al}$} & \multicolumn{2}{|c|}{$+\mathrm{TiO}_{2}$} & \multicolumn{2}{|c|}{$+\left(\mathrm{Al}+\mathrm{TiO}_{2}\right)$} \\
\hline \multirow{5}{*}{$1000^{\circ} \mathrm{C}$} & Porosidade aberta (\%) & \multicolumn{2}{|c|}{$12,5 \pm 0,6$} & \multicolumn{2}{|c|}{$12,4 \pm 0,1$} & \multicolumn{2}{|c|}{$13,1 \pm 1,2$} & \multicolumn{2}{|c|}{ - } \\
\hline & CMOR (MPa) & \multicolumn{2}{|c|}{$2,4 \pm 0,4$} & \multicolumn{2}{|c|}{$5,2 \pm 0,8$} & \multicolumn{2}{|c|}{$2,9 \pm 0,3$} & \multicolumn{2}{|c|}{ - } \\
\hline & Módulo elástico (GPa) & $1,8^{*}$ & $1,7^{\#}$ & $4,3^{*}$ & $4,8^{\#}$ & $1,4^{*}$ & $1,2^{\#}$ & \multicolumn{2}{|c|}{ - } \\
\hline & Flecha $(\mu \mathrm{m})$ & $80^{*}$ & $205^{\#}$ & $8^{*}$ & $148^{\#}$ & $198^{*}$ & $461^{\#}$ & \multicolumn{2}{|c|}{-} \\
\hline & Def. "plástica" (\%) & $45^{*}$ & $50^{\#}$ & $48^{*}$ & $47^{\#}$ & $57 *$ & $59^{\#}$ & \multicolumn{2}{|c|}{ - } \\
\hline \multirow{5}{*}{$1500^{\circ} \mathrm{C}$} & Porosidade aberta (\%) & \multicolumn{2}{|c|}{ - } & \multicolumn{2}{|c|}{ - } & \multicolumn{2}{|c|}{$11,9 \pm 0,6$} & \multicolumn{2}{|c|}{$12,5 \pm 0,4$} \\
\hline & CMOR (MPa) & \multicolumn{2}{|c|}{-} & \multicolumn{2}{|c|}{ - } & & 0,3 & \multicolumn{2}{|c|}{$6,2 \pm 0,8$} \\
\hline & Módulo elástico (GPa) & \multicolumn{2}{|c|}{ - } & \multicolumn{2}{|c|}{-} & $1,7^{*}$ & $1,5^{\#}$ & $3,4^{*}$ & $3,3^{\#}$ \\
\hline & Flecha $(\mu \mathrm{m})$ & \multicolumn{2}{|c|}{-} & \multicolumn{2}{|c|}{-} & $134 *$ & $329^{\#}$ & $169^{*}$ & $336^{\#}$ \\
\hline & Def. "plástica" (\%) & \multicolumn{2}{|c|}{-} & \multicolumn{2}{|c|}{ - } & $65^{*}$ & $63^{\#}$ & $61 *$ & $59^{\#}$ \\
\hline
\end{tabular}

*Resultados obtidos aplicando-se uma carga equivalente a $40 \%$ do CMOR.

${ }^{\#}$ Resultados obtidos aplicando-se uma carga equivalente a $80 \%$ do CMOR.

Tabela IX - Resultados para a porosidade e propriedades mecânicas de acordo com [55].

[Table IX - Porosity and mechanical properties results according to [55].]

\begin{tabular}{|c|c|c|c|c|c|c|c|c|}
\hline \multirow[b]{2}{*}{$\mathrm{T}_{\text {queima }}$} & \multirow[b]{2}{*}{$\begin{array}{c}\text { Características/ } \\
\text { Propriedades }\end{array}$} & \multicolumn{7}{|c|}{ Composições } \\
\hline & & \multicolumn{2}{|c|}{$\begin{array}{c}\text { Isenta de } \\
\text { aditivos }\end{array}$} & \multicolumn{2}{|c|}{$+\mathrm{Al}$} & $+\mathrm{TiO}_{2}$ & \multicolumn{2}{|c|}{$+\left(\mathrm{Al}+\mathrm{TiO}_{2}\right)$} \\
\hline \multirow{5}{*}{$1000^{\circ} \mathrm{C}$} & Porosidade aberta (\%) & \multicolumn{2}{|c|}{12,5} & \multicolumn{2}{|c|}{12,4} & - & \multicolumn{2}{|c|}{11,7} \\
\hline & CMOR (MPa) & \multicolumn{2}{|c|}{3,6} & \multicolumn{2}{|c|}{5,8} & - & \multicolumn{2}{|c|}{4,5} \\
\hline & Módulo elástico (GPa) & $2,0^{*}$ & $1,7^{\#}$ & $3,2^{*}$ & $3,3^{\#}$ & - & $3,4^{*}$ & $3,1^{\#}$ \\
\hline & Flecha $(\mu \mathrm{m})$ & $168^{*}$ & $338^{\#}$ & $156^{*}$ & $274^{\#}$ & - & $96^{*}$ & $197^{\sharp}$ \\
\hline & Def. “plástica” (\%) & $63^{*}$ & $55^{\#}$ & $58^{*}$ & $52^{\#}$ & - & $51 *$ & $43^{\#}$ \\
\hline \multirow{5}{*}{$1500^{\circ} \mathrm{C}$} & Porosidade aberta (\%) & \multicolumn{2}{|c|}{11,5} & \multicolumn{2}{|c|}{13,4} & - & \multicolumn{2}{|c|}{12,5} \\
\hline & CMOR (MPa) & \multicolumn{2}{|c|}{3,1} & \multicolumn{2}{|c|}{5,3} & - & \multicolumn{2}{|c|}{6,2} \\
\hline & Módulo elástico (GPa) & $2,2^{*}$ & $1,9^{\#}$ & $3,5^{*}$ & $3,6^{\#}$ & - & $3,4 *$ & $3,3^{\#}$ \\
\hline & Flecha $(\mu \mathrm{m})$ & $120^{*}$ & $332^{\#}$ & $158^{*}$ & $276^{\#}$ & - & $168^{*}$ & $336^{\#}$ \\
\hline & Def. "plástica" (\%) & $60 *$ & $65^{\#}$ & $64^{*}$ & $61^{\#}$ & - & $61^{*}$ & $59^{\#}$ \\
\hline
\end{tabular}

Tabela X - Resultados da avaliação da resistência ao choque térmico de acordo com [36].

[Table X-Results of the thermal shock resistance tests according to [36].]

\begin{tabular}{lcccccccc}
\hline & \multicolumn{3}{c}{$1000{ }^{\circ} \mathrm{C}$} & \multicolumn{4}{c}{$1500{ }^{\circ} \mathrm{C}$} \\
& $\begin{array}{c}\text { Isenta de } \\
\text { aditivos }\end{array}$ & $+\mathrm{Al}$ & $+\mathrm{TiO}_{2}$ & $+\left(\mathrm{Al}+\mathrm{TiO}_{2}\right)$ & $\begin{array}{c}\text { Isenta de } \\
\text { aditivos }\end{array}$ & $+\mathrm{Al}$ & $+\mathrm{TiO}_{2}$ & $+\left(\mathrm{Al}+\mathrm{TiO}_{2}\right)$ \\
\hline CMOR 0 CT (MPa) & 2,4 & 5,2 & 2,9 & - & - & - & 2,4 & 6,2 \\
CMOR 1 CT (MPa) & 2,0 & 4,8 & 2,9 & - & - & - & 1,8 & 6,3 \\
CMOR 5 CT (MPa) & 1,5 & 3,2 & 2,0 & - & - & - & 1,6 & 5,4 \\
Perda 0-1 CT (\%) & 17 & 8 & 0 & - & - & - & 25 & 0 \\
Perda 0-5 CT (\%) & 38 & 38 & 31 & - & - & - & 33 & 13 \\
\hline
\end{tabular}

a combinação $\mathrm{TiO}_{2}+\mathrm{Al}+\mathrm{Si}$ proporcionaria ao sistema $\mathrm{MgO}-\mathrm{C}$, uma vez que Aneziris aparenta ter aplicado esse trio de aditivos apenas ao sistema $\mathrm{Al}_{2} \mathrm{O}_{3}-\mathrm{ZrO}_{2}-\mathrm{C}$. Também se observa que não teriam sido realizados testes em que 
Tabela XI - Resultados da avaliação da resistência ao choque térmico de acordo com [55]. [Table XI - Results of the thermal shock resistance tests according to [55].]

\begin{tabular}{lcccccccc}
\hline & \multicolumn{3}{c}{$1000{ }^{\circ} \mathrm{C}$} & \multicolumn{4}{c}{$1500{ }^{\circ} \mathrm{C}$} \\
& $\begin{array}{c}\text { Isenta de } \\
\text { aditivos }\end{array}$ & $+\mathrm{Al}$ & $+\mathrm{TiO}_{2}$ & $+\left(\mathrm{Al}+\mathrm{TiO}_{2}\right)$ & $\begin{array}{c}\mathrm{Isentade} \\
\text { aditivos }\end{array}$ & $+\mathrm{Al}$ & $+\mathrm{TiO}_{2}$ & $+\left(\mathrm{Al}^{+} \mathrm{TiO}_{2}\right)$ \\
\hline CMOR 0 CT (MPa) & 3,6 & 5,8 & - & 4,5 & - & - & - & 6,2 \\
CMOR 1 CT (MPa) & 3,0 & 4,9 & - & 4,4 & - & - & - & 6,3 \\
CMOR 5 CT (MPa) & 2,2 & 3,7 & - & 3,1 & - & - & - & 5,4 \\
Perda 0-1 CT (\%) & 15 & 16 & - & 3 & - & - & - & 0 \\
Perda 0-5 CT (\%) & 38 & 36 & - & 32 & - & - & - & 13 \\
\hline
\end{tabular}

composições contendo whiskers "dumbbell-shaped" de $\mathrm{Al}_{4} \mathrm{C}_{3}, \mathrm{Al}_{2} \mathrm{OC}$ e $\mathrm{Al}_{2} \mathrm{O}_{4} \mathrm{C}$ fossem submetidas ao contato com o metal ou com as escórias metalúrgicas líquidas. Esses ensaios seriam de grande importância, pois mostrariam o comportamento dessas estruturas quanto à resistência à corrosão química causadas por outras substâncias que não as fontes de oxigênio gasosas. A respeito desses whiskers compostos por alumínio, outra questão cuja análise deve ser de grande interesse para que realmente se consiga interferir no desenvolvimento da microestrutura do refratário diz respeito a como eles se formam. Isso porque Aneziris et al não apresentam qualquer explicação sobre a evolução dessas estruturas, assim como havia sido feito para o caso do $\beta$-SiC. A composição dos "beads" desses whiskers, por exemplo, não chega a ser comentada nos artigos.

\section{AGENTES DE ACOPLAGEM}

A baixa molhabilidade do grafite é uma conseqüência da sua estrutura cristalina laminar, pois, como a formação de suas partículas ocorre preferencialmente pela quebra da estrutura em planos paralelos a essas lâminas (já que elas se mantém ligadas apenas por forças de Van der Waals fracas), as superfícies formadas acabam não possuindo uma concentração significativa de ligações primárias insatisfeitas [8]. Isso então leva as partículas de grafite a apresentarem uma energia superficial naturalmente baixa, o que resulta em uma reduzida capacidade para interagir com o meio, seja através de interações físicas ou de reações químicas, as quais seriam necessárias para promover a molhabilidade. Esse comportamento também será responsável pelas interfaces fracas que se formam entre as partículas de grafite e a fase matriz do refratário, já que a adesão nas interfaces também é uma conseqüência de interações físico-químicas. Nisso, tais regiões tornam-se ainda mais propícias para o desenvolvimento de processos de degradação, pois sua baixa resistência facilita a penetração do metal, das escórias e/ou de gases oxidantes. Inclusive, é possível presumir que a própria pressão exercida pelos voláteis gerados com o aquecimento do refratário pode acabar por romper as interfaces formadas pelo grafite. Diversas técnicas têm sido desenvolvidas com o propósito de melhorar a molhabilidade do grafite pelos meios líquidos dispersantes e, com isso, beneficiar a processabilidade dos refratários contendo carbono, principalmente em se tratando de concretos. No caso das técnicas voltadas para meios dispersantes aquosos, o uso de agentes surfactantes é revisado de forma abrangente por Oliveira et al [8], enquanto Zhang e Lee [3] dão ênfase às técnicas de formação de micropellets e briquetes de grafite e às técnicas de recobrimento do grafite por substâncias molháveis pela água $\left(\mathrm{SiC}, \mathrm{Al}_{2} \mathrm{O}_{3}, \mathrm{TiO}_{2}\right.$ e $\left.\mathrm{ZrO}_{2}\right)$. Segundo Oliveira et al, a viabilidade dos surfactantes é limitada pelo prejuízo que eles causam à reologia de suspensões altamente concentradas, tal como são as composições refratárias. Já quanto às técnicas de recobrimento, como estas representam uma etapa a mais para a preparação das matérias-primas e muitas vezes envolvem processos dispendiosos e inadequados para a produção em larga escala, já é possível concluir que seus custos formam a principal barreira para sua viabilidade. Além disso, de acordo com Zhang e Lee, a eficácia que as técnicas de recobrimento demonstram nos testes de molhabilidade laboratoriais parece nem sempre se refletir quando as mesmas são aplicadas à composição refratária definitiva. Quanto às técnicas de produção de micropellets e briquetes, estas demonstraram ser realmente efetivas para facilitar a incorporação do grafite às composições de concretos refratários. Porém, além de também exigirem o acréscimo de mais uma etapa ao processo produtivo, os micropellets e briquetes são porosos e não permitem que as partículas de grafite fiquem homogeneamente distribuídas pela microestrutura do refratário, levando à degradação de suas propriedades mecânicas e de resistência à corrosão. Assim, verifica-se que todas as técnicas já criadas para promover a dispersão do grafite em meios aquosos ainda precisam ser desenvolvidas para que se consiga promover ganhos realmente representativos à processabilidade do refratário, ou pelo menos para que esses ganhos sejam compensadores frente ao aumento dos custos de produção que elas inevitavelmente vão causar.

Passando-se à qualidade da dispersão do grafite em líquidos orgânicos (como as resinas termofixas), embora não tenham sido encontrados estudos que tratassem especificamente desses sistemas, acredita-se que os mesmos três conjuntos de técnicas comentados acima também poderiam ser cogitados para melhorá-la. Porém, é quase certo que mesmas desvantagens e inconvenientes apontados surgiriam. Entretanto, é possível que ainda uma quarta técnica pudesse ser considerada para promover uma 
melhor dispersão do grafite e também dos agregados de óxidos nas resinas termofixas utilizadas como ligantes. Essa técnica envolveria o uso dos aditivos denominados como agentes de acoplagem. Embora sejam mais conhecidos pelos seus benefícios às propriedades dos compósitos de matriz polimérica, os agentes de acoplagem na verdade já encontram um importante nicho de aplicação na indústria cerâmica, mais especificamente, na produção de cerâmicas por meio do processo de conformação por injeção. Neste processo, polímeros termoplásticos ou termofixos servem como meios dispersantes e como veículos para partículas cerâmicas, permitindo sua moldagem como peças de formatos complexos. Depois de moldada, a peça passa por etapas em que o polímero será removido cuidadosamente. Nessas composições entre polímeros e partículas cerâmicas (em que tais partículas podem representar até mais de $80 \%$ p da composição total [57]), os agentes de acoplagem são adicionados por serem capazes de proporcionar os seguintes benefícios ao processo de injeção [58-60]: facilitam e otimizam a desaglomeração e dispersão da fração sólida; aumentam a molhabilidade da fração sólida pelo polímero viscoso; aumentam a hidrofobia da interface polímero/partícula, reduzindo assim a absorção de água pela peça; reduzem a viscosidade da composição durante o processamento; possibilitam um maior teor de sólidos na composição; e otimizam as propriedades mecânicas da peça conformada, como sua resistência ao impacto. Todas essas melhorias advêm da habilidade dos agentes de acoplagem para promover a adesão entre polímeros e sólidos diversos (que serão denominados aqui pelo termo "filler"), gerando assim interfaces resistentes entre eles. Logo se observa que todos os benefícios citados também seriam de grande interesse para os refratários ligados por resinas, sendo a formação de uma interface hidrofóbica particularmente interessantes para aqueles que contêm óxidos susceptíveis à hidratação, como o $\mathrm{MgO}$. Apesar disso, não foram encontrados na literatura quaisquer estudos que avaliassem ou mesmo considerassem a possibilidade de aplicar esses aditivos na produção de refratários resinados.

Assim, com o intuito de analisar as possibilidades de aplicação desses aditivos na composição refratária, os próximos tópicos fazem uma abordagem geral da química dos agentes de acoplagem, observando as condições básicas necessárias para que eles atuem, seus métodos de aplicação, e se já existiriam aditivos próprios para os componentes dos refratários $\mathrm{MgO}-\mathrm{C}$ (ou seja, as resinas fenólicas, o grafite e o óxido de magnésio).

\subsection{A Química dos Agentes de Acoplagem}

Os agentes de acoplagem se caracterizam por suas estruturas moleculares bifuncionais, na qual cada funcionalidade será responsável por interagir com uma das duas fases que precisam ser compatibilizadas (ou seja, a fase polimérica e o "filler"), formando uma espécie de ponte entre elas. A interação com o "filler" deve ocorrer por meio de ligações químicas primárias, o que exige que ao menos a superfície das partículas ou das fibras seja reativa para com o aditivo. Já a interação com a fase polimérica pode ocorrer tanto por meio de ligações químicas primárias (formadas por reações de substituição, grafitização ou adição) como por simples interações físico-químicas (pontes de hidrogênio, interação ácido-base, atração eletrostática ou emaranhamento) [60]. De acordo com a composição química, os agentes de acoplagem podem ser distinguidos em diversas classes, sendo os silanos e os titanatos as duas principais. Outras como as dos zirconatos, zircoaluminatos e aluminatos têm seu uso restrito principalmente por questões de custo. Já a classe dos polímeros funcionalizados tem obtido sucesso justamente por seu custo reduzido em relação às outras citadas, mas dificuldades para a sua síntese limitam a variedade de "fillers" com os quais esses polímeros podem ser empregados [59]. Os silanos são os agentes de acoplagem mais largamente aplicados na indústria atual, uma popularidade que se deve, entre outros motivos, a sua compatibilidade para com uma grande variedade de polímeros e "fillers" e a alguns aspectos práticos em seu uso (facilidade de dispersão, estabilidade química, etc.) [59]. No entanto, logo se verifica que algumas condições básicas para que esses aditivos atuem entram em contradição com as características e com alguns aspectos desejados aos refratários resinados. A primeira dessas condições seria a necessidade da presença de água no meio para hidratar os grupos alcóxi (RO-) que compõem a molécula do silano (ver Tabela XII), pois é nesta reação que se formam os grupos silanóis $(\mathrm{Si}-\mathrm{OH})$ que serão responsáveis por interagir com a superfície do "filler" [59, 60]. Porém, como discutido anteriormente, a presença de água nos refratários de $\mathrm{MgO}-\mathrm{C}$ é indesejável, devendo-se sempre procurar minimizar o seu teor. Existem algumas espécies de silanos que já apresentam os grupos silanóis formados e, portanto, não precisam ser hidratados, mas estes ainda usam a água como um solvente [60]. Outra condição básica para a ação dos silanos é que o "filler" precisa possuir uma densidade suficiente de hidroxilas $(\mathrm{OH})$ em sua superfície, pois são esses os grupos com os quais os silanóis reagirão preferencialmente $[59,60]$. Ou seja, materiais da composição refratária como o grafite e o negro de fumo, que não apresentam naturalmente uma grande quantidade de hidroxilas superficiais, não seriam reativos para com os silanos. A aplicação de certos prétratamentos a esses "fillers" (como ataques com ácidos) para a inserção de grupos químicos na superfície das partículas poderia torná-los mais reativos para com os silanos. No entanto, esse procedimento não seria conveniente por uma questão de custos e pelas complicações que traz ao processamento do refratário. Ainda outros dois aspectos negativos do uso de silanos são a formação de alcoóis (R$\mathrm{OH})$ com a hidratação dos grupos alcóxi, e a formação de água quando ocorre a reação entre os grupos silanóis e os grupos hidroxila presentes na superfície do "filler". Ou seja, mais uma vez surge o problema da presença da água, e ainda há o aumento do volume de substâncias que serão volatilizadas e que precisarão ser removidas durante a carbonização do refratário. Portanto, em razão de todos esses aspectos, chega-se a conclusão que os agentes silanos 
não seriam, em primeira análise, os mais promissores para a aplicação em refratários resinados. Isso leva à mudança do foco para a classe dos agentes titanatos, os quais se destacam justamente por sua capacidade de superar algumas das limitações dos silanos.

Primeiramente, os titanatos não precisam ser hidratados ou sofrer qualquer outro tipo de ativação prévia, estando já aptos para reagir com o "filler". Além disso, suas reações não exigem a presença de grupos hidroxila na superfície desse último, podendo tais reações ser do tipo solvólise, que liberam alcoóis como subprodutos, ou por mecanismos de coordenação, os quais necessitam de prótons livres na superfície do "filler" e não geram subprodutos [59]. Apesar dos mecanismos de coordenação ainda não serem completamente compreendidos, é interessante frisar que a presença de prótons livres é comum à maioria dos "fillers", o que confere aos titanatos um campo de aplicação mais amplo em comparação ao dos silanos [59]. O negro de fumo, por exemplo, é susceptível à interação com os titanatos [59]. Os titanatos também se destacam por atuarem simultaneamente como plastificantes da fase polimérica, contribuindo assim de uma segunda forma para com a fluidez do sistema compósito. E tanto eles como os silanos podem agir como catalisadores de algumas reações químicas no polímero [58, 59]. No entanto, no caso das resinas termofixas aplicada aos refratários, ainda é incerto se essa ação catalisadora seria desejável ou não. Por um lado, ela poderia reduzir a necessidade da adição de um agente de cura, mas por outro lado, ela seria prejudicial caso levasse ao endurecimento precoce da resina. Não se sabe se essas reações causadas pelos agentes de acoplagem já ocorreriam à temperatura ambiente, e se seriam possíveis tanto aos resóis como às novolacas. Para compreender outras diferenças fundamentais entre titanatos e silanos, a estrutura molecular básica e alguns exemplos desses agentes de acoplagem são apresentados na Tabela XII. Verifica-se em ambos a presença dos grupos alcóxi (RO), responsáveis por interagir com a superfície do "filler", e dos grupos organofuncionais (Y), que devem interagir com a fase polimérica. Nos silanos parece ser padrão a presença de três grupos alcóxi (sendo esses, geralmente, do tipo metóxi $\left(-\mathrm{O}-\mathrm{CH}_{3}\right)$, possivelmente por ser um dos mais reativos [60]), enquanto para os titanatos o fator " $\mathrm{n}$ " em sua estrutura molecular básica indica que é possível haver de uma a três unidades dessa funcionalidade.

Apesar disso, verifica-se na literatura o predomínio de agentes titanatos com três funções $\mathrm{Y}$ e apenas uma função RO (embora essa possa ser tão complexa quanto o 2,2-bis(2-propenolatometil)butanolato, presente no exemplo $\mathrm{B}$ da Tabela XII). A presença de até três grupos Y para os titanatos significa uma melhor compatibilização com a fase polimérica [59]. Já a presença de três grupos alcóxi nos silanos permite que suas moléculas se polimerizem entre si, levando assim à formação de um verdadeiro polisiloxano na superfície do "filler" $[59,60]$, como ilustra a Fig. 6a. Este é um comportamento muito interessante, pois significa que a molécula de siloxano não precisa estar aderida diretamente à superfície do "filler" para participar do recobrimento compatibilizante. Com isso, esse recobrimento pode na verdade ser constituído por várias camadas do agente de acoplagem, o que significa que quanto maior o teor de silanos adicionados, maior será a espessura desse recobrimento.

Já no caso dos titanatos, sendo usual a presença de um único grupo alcóxi, a polimerização não é possível, formando-se assim apenas uma monocamada do aditivo na interface polímero/"filler", como exemplifica a Fig. 6b. Isso significa que o teor ideal dos titanatos seria muito bem

Tabela XII - Estrutura molecular padrão dos silanos e titanatos, e alguns exemplos das moléculas desses aditivos. [Table XII - Silanes and titanates standard molecular structures and some examples of these additives molecules.]

\begin{tabular}{|c|c|c|}
\hline & Silanos & Titanatos \\
\hline $\begin{array}{l}\text { Estrutura } \\
\text { molecular } \\
{[60,59]}\end{array}$ & $(\mathrm{RO})_{3} \mathrm{Si}\left(-\mathrm{R}^{\prime} \mathrm{Y}\right)$ & $(\mathrm{RO})_{\mathrm{n}}-\mathrm{Ti}-\mathrm{i}\left(-\mathrm{O} X \mathrm{R}^{\prime} \mathrm{Y}\right)_{4-\mathrm{n}}$ \\
\hline \multirow[t]{2}{*}{ Exemplo A } & $\begin{array}{c}\mathrm{OCH} \mathrm{O}_{3} \\
\mathrm{I} \\
\mathrm{H}{ }_{3} \mathrm{CO}-\mathrm{Si}-\left[\mathrm{CH}_{2}\right]_{3}-\mathrm{NH}-\left[\mathrm{CH}_{2}\right]_{2}-\mathrm{NH}_{2} \\
\mathrm{OCH}_{3}\end{array}$ & $\left.\mathrm{CH}_{3}-\mathrm{CH}_{-\mathrm{O}}-\mathrm{Ti}-\mathrm{O}-\mathrm{C}-\mathrm{C}_{17} \mathrm{H}_{35}\right]_{3}$ \\
\hline & $\begin{array}{c}{[\mathrm{n}-(\beta \text {-aminoetil })-\gamma \text {-aminopropil }]} \\
\text { trimetoxisilano }\end{array}$ & titânio(IV) 2-propanolato, tris(isooctadecanoato-O) \\
\hline \multirow[t]{2}{*}{ Exemplo B } & 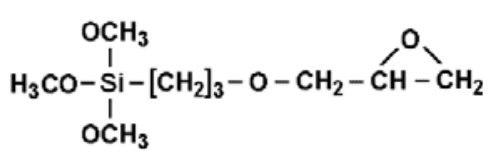 & 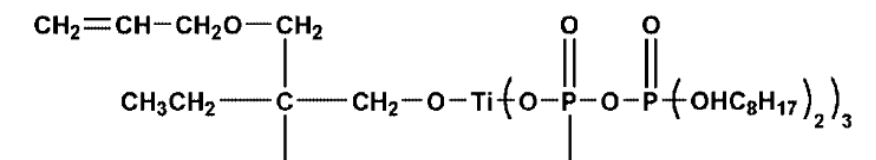 \\
\hline & $\gamma$-Glicidoxipropiltrimetoxisilano & $\begin{array}{c}\mathrm{CH}_{2}=\mathrm{CH}-\mathrm{CH}_{2} \mathrm{O}-\mathrm{CH}_{2} \quad \mathrm{OH} \\
\text { titânio(IV) } 2,2 \text {-bis(2-propenolatometil)butanolato, tris(dioctil) } \\
\text { pirofosfato-O }\end{array}$ \\
\hline
\end{tabular}


definido, variando em função das características da superfície e da área superficial específica do "filler". Inclusive, determinar esse teor é uma das dificuldades para o uso dos titanatos em comparação aos silanos, já que a diferença entre o teor adequado e o excesso acaba sendo mais estreita para os primeiros. Além de impactar nos custos, o excesso desses aditivos também pode causar prejuízos às propriedades do produto final [58].

Há dois tipos principais de grupos RO para os titanatos: os monoalcóxi e os neoalcóxi. Os monoalcóxi (como o 2-propanolato do exemplo A da Tabela XII) são os mais simples e ligam-se à superfície do "filler" através das reações de solvólise. Os neoalcóxi são estruturas mais complexas (como o 2,2-bis(2-propenolatometil)butanolato do exemplo B da Tabela XII), e reagem pelos vantajosos mecanismos de coordenação comentados anteriormente [59]. Além disso, em comparação aos monoalcóxi, os titanatos neoalcóxi proporcionam propriedades superiores ao compósito final, e também possuem maior estabilidade térmica, resistindo a temperaturas de mais de $200^{\circ} \mathrm{C}$ em meios isentos de água [59]. Tal estabilidade poderia representar uma vantagem muito importante para a aplicação em refratários, pois ela possivelmente significa que o agente de acoplagem continuaria atuando no reforço das interfaces em faixas de temperatura nas quais a saída de voláteis estaria ocorrendo em taxas significantes devido à cura da resina. Assim, pelo conjunto de características que apresentam, os titanatos seriam os aditivos mais promissores para conferir aos refratários resinados os desejados ganhos em processabilidade, qualidade da microestrutura final e propriedades físicas. $\mathrm{Na}$ realidade, os zirconatos teriam

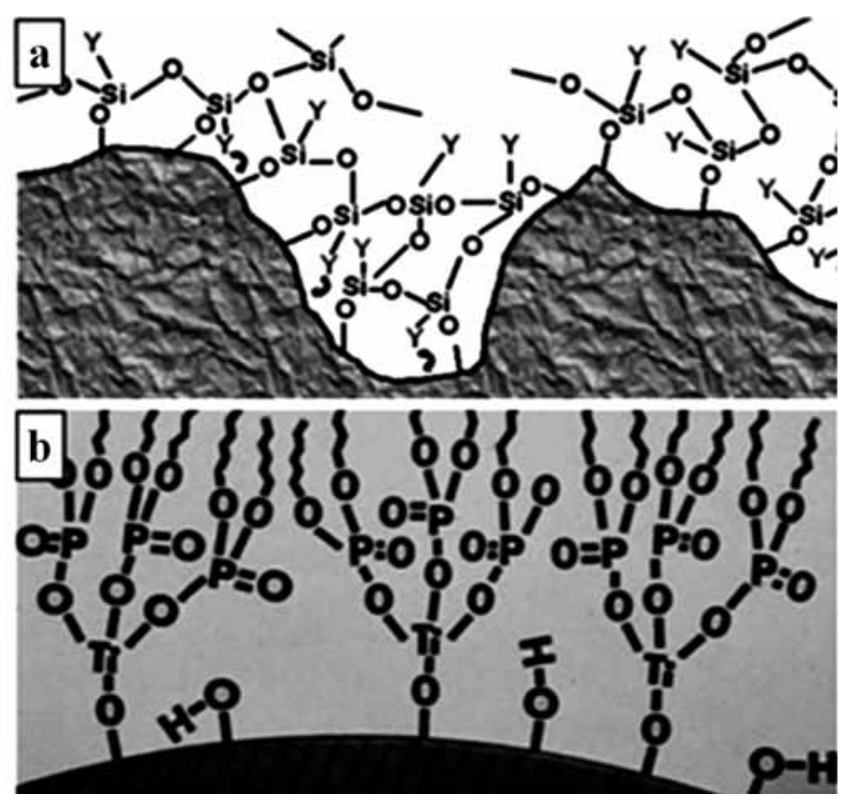

Figura 6: Ilustrações do arranjo formado pelas moléculas dos agentes de acoplagem silanos (a) e titanatos (b) sobre a superfície do "filler" [60, 61].

[Figure 6: Illustrations of the structures developed by silanes (a) and titanates (b) molecules on the filler surface [60, 61].] as mesmas potencialidades que os titanatos, já que suas estruturas químicas e aplicações são completamente análogas [59]. Porém, os zirconatos apresentam a desvantagem de um custo cerca de duas vezes superior ao dos titanatos [59].

\subsection{Métodos para a aplicação dos agentes de acopla- gem}

Os agentes de acoplagem podem ser encontrados na forma de pós, pellets ou como líquidos, sendo usualmente adicionados em teores de até $2 \%$ em peso em relação à quantidade do "filler", quantidade que deve ser definida em função de variáveis como a área superficial do "filler" e da técnica usada para a aplicação do aditivo. Quanto a essas técnicas, três modalidades são possíveis [59, 60]: pulverizando o agente de acoplagem, na forma pura, sobre o "filler" seco em agitação e sob aquecimento; adicionando-o como uma solução ao "filler" em suspensão, ou pulverizando essa solução sobre o "filler" seco; adicionando-o diretamente ao polímero na forma pura ou como um "masterbatch", isso antes ou em conjunto com a adição do "filler". As duas primeiras técnicas, nos quais o "filler" acaba sendo prérecoberto pelo aditivo, possuem a vantagem da possibilidade de remover os subprodutos que podem ser formados com as reações dos agentes de acoplagem, como alcoóis e água. Já a terceira técnica, que pode ser denominada como um tratamento "in-situ", vem sendo uma das mais aplicadas pela indústria por sua simplicidade e possíveis vantagens quanto a custos [60], o que também faria dela a mais interessante para a aplicação na produção de refratários que esta sendo cogitada aqui. Nesse tratamento "in-situ", é essencial que o aditivo seja muito bem distribuído pela matriz polimérica, evitando-se que ocorram pontos de concentração, e que sejam aplicadas taxas de cisalhamento suficientemente elevadas durante a mistura para que o agente de acoplagem reaja completamente [59]. No entanto, para que sua migração até a interface com o "filler" seja possível e eficaz, o agente de acoplagem não deve reagir prematuramente com o polímero [60]. Ainda assim, como essa migração dificilmente ocorrerá por completo, o tratamento "in-situ" acaba por exigir o uso de teores mais elevados do aditivo que as demais técnicas [60].

A determinação do teor de agente de acoplagem a ser usado deve ser feita com atenção, pois seu excesso pode prejudicar as propriedades finais do produto [58]. Outra decisão que exige cuidado está na própria escolha do aditivo, isso em vista do grande número de substâncias existentes para cada uma das classes de agentes de acoplagem. É necessário montar a molécula de forma que esta apresente o grupo organofuncional compatível com polímero, e o grupo alcóxi compatível com o “filler”. Porém, na aplicação em refratários de $\mathrm{MgO}-\mathrm{C}$, haveria ao menos duas espécies distintas de "fillers" para interagir com o agente de acoplagem, que seriam o $\mathrm{MgO}$ e os "flakes" de grafite, sendo ainda possível a presença do negro de fumo ou de outras fontes de carbono. Assim, nos tópicos a seguir se analisam que tipos de aditivos e/ou funcionalidades seriam promissoras em um sistema constituído por esses 
materiais mais a resina fenólica. Será dada ênfase especial aos agentes de acoplagem do tipo titanato, em vista das suas já comentadas vantagens frente aos silanos e aos zirconatos, mas também em razão da possibilidade de que eles possam contribuir como uma fonte de titânio para a formação das fases especiais que foram apresentadas no capítulo 5, o que tornaria seu uso ainda mais vantajoso.

\subsection{Agentes de acoplagem para as resinas fenólicas}

$\mathrm{Na}$ literatura geral sobre agentes de acoplagem e nos próprios "folders" de empresas que produzem esses aditivos é possível encontrar indicações sobre os grupos organofuncionais (Y) mais apropriados para uso com determinado tipo de polímero. No entanto, as recomendações nem sempre são as mesmas. No caso de agentes silanos, Weissenbach e Mack [60] citam os grupos amina e metacrilóxi como adequados para as resinas fenólicas. Já em um guia de seleção desenvolvido pela empresa Famasil [62], no qual são apresentados rankings de grupos organofuncionais para diversos polímeros, coloca-se como a melhor opção para as resinas fenólicas o grupo ureido, ficando os grupos mercapto, epóxi e amino em segundo lugar. Ainda outra empresa, a United Chem. Techn. Inc., também recomenda os mesmos grupos amina, epóxi e mercapto, mais os grupos diamina e cloroalquil [63, 64]. Essas funções químicas podem ser observadas na Tabela XIII. Não foram encontrados guias de funcionalidades semelhantes para os agentes titanatos. Porém, não se vê motivos para que esses grupos organofuncionais compatíveis com as resinas fenólicas se modifiquem significativamente com a mudança do tipo de agente de acoplagem.

Já a empresa Kenrich Petrochem. fornece tabelas em que são indicados os seus titanatos e zirconatos, incluindo suas dosagens, mais adequados para diversas combinações de polímeros e "fillers". No caso de sistemas compostos por resinas fenólicas, os aditivos sugeridos são apresentados na Tabela XIV, sendo suas composições e estruturas químicas descritas na Tabela XV. Inclusive, nesta última tabela podese verificar grupos $\mathrm{Y}$ semelhantes aos dos silanos, como o metacrilóxi para o aditivo KR 238M, e o grupo amina, para o NZ 97. Outros agentes de acoplagem ainda apresentam grupos Y do tipo alcano, como o LICA 38. Verifica-se pela Tabela XIV que o teor do agente de acoplagem algumas vezes é baseado na quantidade da resina presente no compósito, ao invés de na quantidade do "filler" (o que seria mais lógico, visto que é a quantidade do "filler" que determina a área da interface). Segundo o pesquisador Salvatore Monte, isso é justificado pelo efeito catalisador que o titânio e o zircônio têm sobre algumas reações que ocorrem na fase polimérica (reações que são definidas pelo termo "repolimerização" [61]), sendo que o teor de $0,4 \%$ em peso do agente de acoplagem em relação à quantidade do polímero levaria

Tabela XIII - Grupos organofuncionais sugeridos pela literatura para os agentes silanos aplicados a resinas fenólicas. ( $\mathrm{R}=$ grupo hidrocarboneto).

[Table XIII - Organofunctional groups suggested in the literature for silanes agents applied to phenolic resins. $(R=$ hydrocarbon group $)$.

\begin{tabular}{|c|c|c|c|c|c|c|c|}
\hline Grupo químico & Amina & Metacrilóxi & Ureido & Mercapto & Epoxi & Diamina & Cloroalquil \\
\hline $\begin{array}{l}\text { Estrutura } \\
\text { molecular }\end{array}$ & $-\mathrm{NH}_{2}$ & & & $-\mathrm{SH}$ & & $-\mathrm{NH}-\mathrm{R}-\mathrm{NH}_{2}$ & $-\mathrm{R}-\mathrm{Cl}$ \\
\hline
\end{tabular}

Tabela XIV - Agentes titanatos e zirconatos da Kenrich Petrochemicals sugeridos para sistemas compósitos com resinas fenólicas.

[Table XIV. Titanates and zirconates by Kenrich Petrochemicals suggested to phenolic resins composites.]

\begin{tabular}{|c|c|c|c|c|c|}
\hline $\begin{array}{l}\text { Agente de } \\
\text { cura da resina }\end{array}$ & Solvente & $\begin{array}{l}\text { Partícula, fibra ou } \\
\text { substrato }\end{array}$ & Efeitos básicos & $\begin{array}{c}\text { Ken-React }{ }^{\circledR} \text { Coupling } \\
\text { Agent }\end{array}$ & Dosagem \\
\hline Amida & Aquoso & $\begin{array}{c}\text { Mineral } \\
\text { Fibra de vidro } \\
\text { Carbono } \\
\text { Kevlar } \\
\end{array}$ & $\begin{array}{c}\text { Dispersão } \\
\text { Reologia } \\
\text { Propriedades físicas } \\
\text { Adesão } \\
\end{array}$ & $\begin{array}{c}\text { LICA 38J : KR 238M } \\
\qquad(1: 3) \\
\text { NZ } 97 \\
\end{array}$ & $0,4 \%$ do polímero \\
\hline \multirow[b]{2}{*}{ Aldeído/ Amina } & \multirow[b]{2}{*}{ Orgânico } & Mineral & $\begin{array}{c}\text { Dispersão } \\
\text { Adesão a metais }\end{array}$ & $\begin{array}{c}\text { LICA } 38 \\
\text { CAPOW NZ 97/H }\end{array}$ & $\begin{array}{l}0,7 \% \text { do mineral } \\
0,5 \% \text { do composto }\end{array}$ \\
\hline & & $\begin{array}{c}\text { Fibra de vidro } \\
\text { Carbono } \\
\text { Kevlar }\end{array}$ & $\begin{array}{l}\text { Propriedades físicas } \\
\text { Adesão } \\
\text { Controle da corrosão }\end{array}$ & NZ 97 & $0,4 \%$ do polímero \\
\hline
\end{tabular}


esse efeito catalisador ao seu nível ótimo. No entanto, nos casos em que a quantidade do "filler" é muito elevada em relação à do polímero, como nos refratários resinados, Monte aconselha que sempre se passe a usá-la como base para calcular a dosagem do agente de acoplagem.

\subsection{Agentes de acoplagem para os óxidos refratários básicos}

Não sendo um "filler" comum na produção de compósitos de matriz polimérica, ou mesmo para o processo de conformação cerâmica por injeção, foram encontrados na literatura somente três trabalhos em que partículas de $\mathrm{MgO}$ precisassem ser submetidas a tratamentos com agentes de acoplagem. Dois deles, de autoria dos japoneses Murata et al $[65,66]$, analisam as propriedades dielétricas de compósitos $\mathrm{LDPE} /$ nano-MgO, sendo que o "filler" recebe um tratamento superficial prévio com agentes silanos, possivelmente com o intuito de otimizar sua dispersão. Porém, além deste tratamento e do tipo de agente silano usado não terem sidos descritos, os resultados e conclusões apresentados não discutem quaisquer conseqüências do seu uso, tendo sido apenas observado que foi obtida uma dispersão homogênea das nanopartículas pela matriz. Já em trabalho de Murali et al [67], o sistema analisado passa a ser PTFE/micro-MgO, que também terá suas propriedades dielétricas avaliadas objetivando a aplicação como um material de substratos para microondas. Novamente o $\mathrm{MgO}$ passa por um tratamento prévio com um agente silano (um fenil trimetóxi silano), mas agora não apenas com o intuito de facilitar sua dispersão pela matriz polimérica, como também para inibir a natureza hidrofílica desse óxido. No entanto, os autores

Tabela XV - Classificação, nome químico e algumas estruturas químicas dos agentes titanatos e zirconatos da Kenrich Petrochemicals.

[Table XV - Classification, chemical compounds and structures of Kenrich Petrochemicals'titanates and zirconates.]

Nome comercial e
estado físico $\quad$ Grupo RO Composição e estrutura química

Titânio IV 2,2-bis(2-propenolatometil)butanolato, tris(dioctil)pirofosfato-O

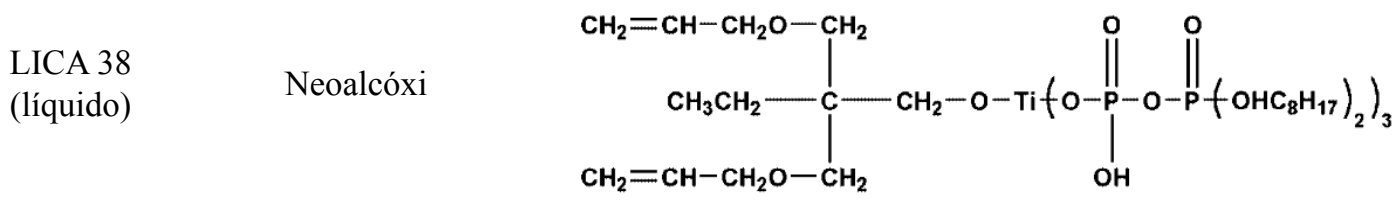

LICA 38J

(líquido)
Neoalcóxi

Titânio IV 2,2-bis(2-propenolatometil)butanolato, tris(dioctil)pirofosfato-O (aduto) 3 mols N,N-dimetilamina-alquil propenoamida

Titânio IV etilenodiolato bis(dioctil)pirofosfato-O, bis(dialquil)

amino alquil-2-metil propenoato)

\begin{tabular}{|c|c|c|}
\hline $\begin{array}{l}\text { KR } 238 \mathrm{M} \\
\text { (líquido) }\end{array}$ & Monoalcóxi & $\left.\left.\right|_{\mathrm{CH}_{2}-\mathrm{O}^{\prime}} ^{\mathrm{CH}_{2}-\mathrm{O}} \underset{\mathrm{OH}}{\mathrm{O}} \stackrel{\mathrm{O}}{\mathrm{O}} \prod_{\mathrm{OP}}^{\mathrm{O}}\left(\mathrm{OC}_{8} \mathrm{H}_{17}\right)_{2}\right]_{2}-\mathrm{nR}_{2} \mathrm{NR}^{1} \mathrm{OC}(\mathrm{O})\left(\mathrm{CH}_{3}\right)=\mathrm{CH}_{2}$ \\
\hline $\begin{array}{l}\text { KR 46B } \\
\text { (líquido) }\end{array}$ & Monoalcóxi & Titânio IV tetrakis(octanolato) (aduto) 2 mols (di-tridecil)hidrogênio fosfito \\
\hline $\begin{array}{l}\text { KR } 44 \\
\text { (líquido) }\end{array}$ & Monoalcóxi & Titânio IV 2-propanolato, tris(3,6-diaza)hexanoato \\
\hline $\begin{array}{l}\text { NZ } 97 \\
\text { (líquido) }\end{array}$ & Neoalcóxi & $\begin{array}{l}\text { Zircônio IV 2,2-bis(2-propenolatometil)butanolato, tris(2-amino)fenolato } \\
\qquad \begin{array}{l}\mathrm{CH}_{2}=\mathrm{CH}-\mathrm{CH}_{2} \mathrm{O}-\mathrm{CH}_{2}=\mathrm{CH}-\mathrm{CH}_{2} \mathrm{O}-\mathrm{CH}_{2}\end{array}\end{array}$ \\
\hline $\begin{array}{l}\text { CAPOW } \\
\text { NZ 97/H (pó) }\end{array}$ & Neoalcóxi & $\begin{array}{c}65 \% \text { NZ } 97+35 \% \text { Hi-Sil }{ }^{\mathrm{TM}} 233 \text { (sílica amorfa sintética, branca, na forma } \\
\text { de pó ou grânulos, produzida pela empresa PPG) }\end{array}$ \\
\hline
\end{tabular}


parecem não considerar a grande facilidade com que o $\mathrm{MgO}$ pode se hidratar já a temperatura ambiente, pois realizaram o tratamento das nanopartículas com o agente silano em um meio aquoso. De fato, a formação do hidróxido de magnésio foi confirmada, justificando então as propriedades dielétricas inferiores apresentadas pelo compósito. Assim, verifica-se que não foram encontrados trabalhos científicos que aplicassem titanatos ou zirconatos, ao invés de silanos, ao $\mathrm{MgO}$, ou mesmo que fizessem a aplicação do agente de acoplagem "in-situ", ao invés de por meio de um tratamento prévio. Portanto, ainda existiriam muitas possibilidades a serem testadas para o $\mathrm{MgO}$. Considerando as semelhanças existentes entre o óxido de magnésio e o óxido de cálcio, também foram pesquisados trabalhos que aplicassem agentes de acoplagem a esse último, mas também não foi encontrado nada deste gênero.

\subsection{Agentes de acoplagem para o grafite}

A aplicação do grafite na forma de "flakes" e com as dimensões normalmente usadas nas composições refratárias (acima de $20 \mu \mathrm{m}$ ) não parece ser muito comum na produção de compósitos de matriz polimérica. $\mathrm{Na}$ literatura foi possível encontrar somente trabalhos que aplicavam agentes de acoplagem a grafites do tipo coloidal, nanométrico e microcristalino, e, principalmente, a fibras de carbono (cuja estrutura pode ser altamente cristalina no caso das fibras classificadas como de alto módulo). Em trabalho de Zhao e Ye [68], são aplicados agentes titanatos para dispersar grafites coloidais $(4 \mu \mathrm{m})$ e nanométricos $(200 \mathrm{~nm}) \mathrm{em}$ uma matriz do polímero polioximetileno. Foram testados cinco tipos de titanatos, sendo que os dois que foram os mais eficazes para esse sistema compósito combinavam grupos alcoóis e amino. A atuação desses aditivos teria sido confirmada através de um ensaio de tração, no qual se verificou que o valor de elongação na ruptura aumentou quatro vezes das amostras sem para as amostras contendo os agentes de acoplagem. O mesmo comportamento foi observado em trabalho de Wang et al [69], no qual o grafite amorfo (microcristalino) foi combinado com um polietileno de baixa densidade. Porém, nesse caso foi utilizado um agente silano para realizar a compatibilização, o qual possuía em sua molécula um grupo éster insaturado e três grupos metóxi. Em ambos os trabalhos, as micrografias apresentadas revelam que o grafite teria ficado homogeneamente distribuído pelas matrizes poliméricas. Já a importância das interfaces na resistência à oxidação de materiais carbonáceos pode ser claramente observada pelos resultados obtidos por Wang e Sherwood [70] com compósitos de resinas fenólicas e fibras de carbono. Nos experimentos desenvolvidos, avaliou-se o efeito do tratamento superficial da fibra e do uso de agentes titanatos na qualidade da interface entre o polímero e a fibra. Um dos métodos de avaliação consistiu na realização de ensaios de termogravimetria (com atmosfera de ar seco) para verificar a susceptibilidade do compósito à oxidação.

Na Fig. 7 pode-se verificar um dos conjuntos de resultados obtidos, comparando os compósitos constituídos por fibras não tratadas, por fibras tratadas com ácido fosfórico, e por fibras tratadas por ácido fosfórico e em que a resina continha algum agente titanato (tetraisopropil titanato (TPT), tetra-n-butil titanato (TBT) e tetrakis(2-etilhexil)titanato (TOT)). Fica claro que o tratamento superficial, e ainda mais a combinação deste com os agentes de acoplagem, aumentaram a resistência da interface, o que então dificultou a penetração do oxigênio. Porém, como os agentes de acoplagem foram aplicados apenas às fibras tratadas, não se sabe se eles conseguiriam interagir com a fibra convencional com a mesma eficácia, e assim proporcionar a mesma melhoria da resistência à oxidação do compósito. Ainda assim, pelos primeiros trabalhos comentados, já é possível afirmar que os agentes de acoplagem realmente são capazes de melhorar a dispersão de alguns tipos de grafite, e isso sem a necessidade de um tratamento superficial prévio. Seria agora necessário verificar se os "flakes" de grafite também seriam susceptíveis a interagir com esses aditivos.

\section{CONCLUSÕES}

Considerando os levantamentos e discussões desenvolvidos neste artigo sobre alguns dos aspectos básicos da composição dos refratários contendo carbono, logo é possível verificar a existência de uma grande diversidade de caminhos em aberto para a realização de melhorias e inovações nestes materiais. Dentre todos, merecem especial destaque aqueles que podem contribuir com a evolução dos concretos contendo carbono resinados, como a busca por fontes de carbono de mais fácil dispersão e o uso dos

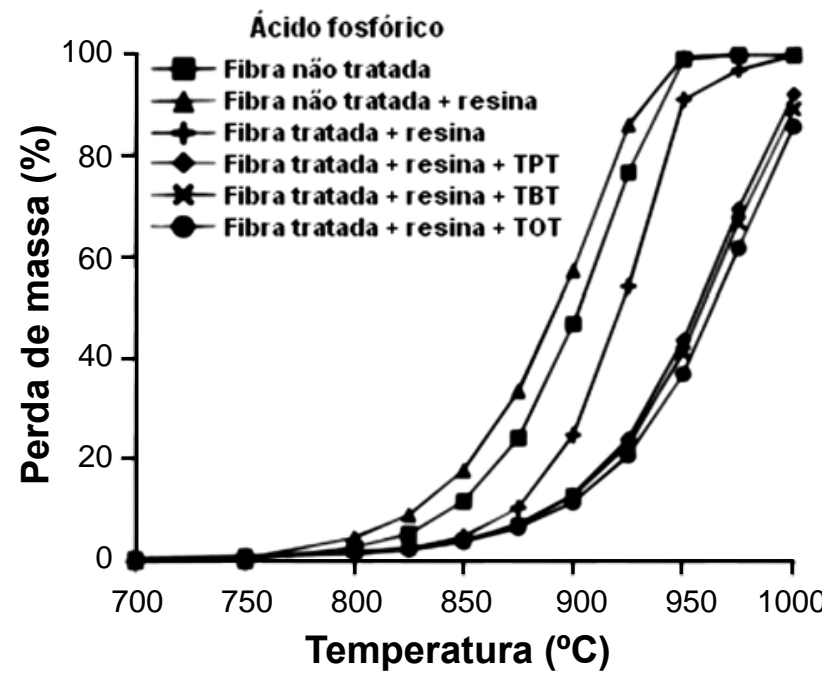

Figura 7: Resultados de termogravimetria para os compósitos de fibra de carbono [70].

[Figure 7: Thermal gravimetric analysis results for carbon fiber composites [70].]

agentes de acoplagem. O grafite microcristalino e o pouco estudado coque de petróleo seriam as principais rotas entre as fontes de carbono, enquanto os titanatos e zirconatos são as famílias de agentes de acoplagem que apresentam as características mais interessantes para serem introduzidas às 
composições refratárias.

Quanto às inovações proporcionadas pela descoberta dos agentes grafitizantes e pela combinação entre antioxidantes metálicos e o $\mathrm{TiO}_{2}$, pôde-se constatar que importantes dúvidas ainda precisariam ser esclarecidas para nortear as pesquisas sobre esses novos procedimentos. Caso contrário, corre-se o risco de se recair no pouco científico, pouco produtivo e oneroso método da tentativa e erro.

Já com relação às resinas fenólicas, sugere-se primeiramente garantir que o processo de seleção destes polímeros (e de seus aditivos e solventes) seja feito com base na análise detalhada de suas características. Apesar da complexidade de tal procedimento pelo número de variáveis envolvidas (razão fenol/formaldeído, distribuição de peso molecular, procedimento de cura, etc.), deve-se considerar que esta sem dúvida seria uma das rotas mais acessíveis para otimizar o desempenho dos refratários contendo carbono em diversos aspectos de relevância.

\section{AGRADECIMENTOS}

Os autores agradecem ao CNPq e à Magnesita Refratários SA pelo apoio proporcionado a esta pesquisa.

\section{REFERÊNCIAS}

[1] W. E. Lee, R. E. Moore, Evolution of in situ refractories in the 20th century, J. Am. Ceram. Soc. 81, 6 (1998) 13851410.

[2] A. R. Studart, R. G. Pileggi, V. C. Pandolfelli, Desenvolvimento de concretos refratários multifuncionais, Cerâmica 47, 301 (2001) 40-44.

[3] S. Zhang, W. E. Lee, Carbon containing castables:current status and future prospects, Brit. Ceram. Trans. J. 101, 1 (2002) 1-8.

[4] M. Marino, Elimination of the exavalent chromium risk on used refractories: experiences with alternative refractories in the various fields of use, Metallurgia Italiana 96, 11-12 (2004) 25-31.

[5] E. Yorita, Resin bonded castable refractories, Taikabutsu Overseas 9, 1 (1988) 32-34.

[6] N. Hiroki, G. Muta, T. Miki, H. Takahashi, T. Itoh, Y. Mizuta, Application of resin bonded monolithic refractories to B.O.F, Taikabutsu Overseas 14, 3 (1993) 19-25.

[7] H. O. Pierson, "Handbook of carbon, graphite, diamond and fullerenes: properties, processing and applications", $1^{\text {st }}$ Ed., Noyes Publ., Park Ridge (1993).

[8] I. R. Oliveira, A. R. Studart, F. A. Silva Júnior, V. C. Pandolfelli, Artigo revisão: Estabilização de suspensões aquosas contendo grafite, Cerâmica 46, 300 (2000) 186195.

[9] E. M. M. Ewais, Carbon based refractories, J. Ceram. Soc. Jap. 112, 10 (2004) 512-532.

[10] C. G. Aneziris, D. Borzov, M. Hampel, J. Ulbricht, Flexibility of $\mathrm{MgO}-\mathrm{C}$ refractories due to bending tests, Proc. $47^{\text {th }}$ Int. Coll. Refractories, Ed. Verlag Stahleisen, Aachen, Alemanha (2004) 51-54
[11] X. Chen, Y. Li, Y. Li, S. Sang, L. Zhao, S. Li, S. Jin, S. $\mathrm{Ge}$, Effect of carbon aggregates on the properties of carbon refractories for a blast furnace, Metal. Mat. Trans. B 41, 2 (2010) 420-429.

[12] C. F. Cooper, Graphite containing refractories, Refract. J. 55, 6 (1980) 11-21.

[13] P. J. F. Harris, New perspectives on the structure of graphitic carbons, Crit. Rev. Solid State Mater. Sci. 30, 4 (2005) 235-253.

[14] L. Zhao, V. Sahajwalla, Interfacial phenomena during wetting of graphite/alumina mixtures by liquid iron, ISIJ Int. 43, 1 (2003) 1-6.

[15] S. I. Popel', B. V. Tsarevskii, V. G. Babkin, Wetting of refractory oxides by metal and slag melts, Refract. Ind. Ceram. 15, 9-10 (1974) 577-582.

[16] R. L. V. Wal, A. J. Tomasek, K. Street, W. K. Thompson, D. R. Hull, Carbon nanostructure examined by lattice fringe analysis of high resolution transmission electron microscopy images, NASA Center for Aerospace Information (2003), disponivel em: $<$ http://gltrs.grc.nasa.gov/reports/ 2003/TM2003-212214.pdf>, acesso em 29/01/ 2010.

[17] "Graphitization heat treatment", IUPAC Compendium of Chemical Terminology - the Gold Book (1997), disponivel em $<$ http://old.iupac.org/goldbook/G02692.pdf $>$, acesso em 30/12/2009.

[18] G. Zoglmeyr, Technical and environmental aspects of the use of phenolic resins in modern-day refractories, Interceram 42, 3 (1993) 145-149.

[19] R. Khanna, J. Spink, V. Sahajwalla, Role of ash impurities in the depletion of carbon from alumina-graphite mixtures in to liquid iron, ISIJ Int. 47, 2 (2007) 282-288.

[20] S. H. Patel, Surface property modifiers, in M. Xanthos, "Functional fillers for plastics", $1^{\text {st }}$ Ed., Wiley-VCH Verlag GmbH \& Co. KGaA, Weinheim, Alemanha (2005) 373-406. [21] "O grafite", Nacional do Grafite, disponível em <http:// www.grafite.com/grafite.htm>, acesso em 31/01/2010.

[22] W. Lian, H. Song, X. Chen, L. Li, J. Huo, M. Zhao, G. Wang, The transformation of acetylene black into onionlike hollow carbon nanoparticles at $1000{ }^{\circ} \mathrm{C}$ using an iron catalyst, Carbon 46, 3 (2008) 525-530.

[23] B. Rand, B. McEnaney, Carbon binders from polymeric resins and pitch, Part I - Pyrolysis behaviour and structure of the carbons, Brit. Ceram. Trans. J. 84, 5 (1985) 157-165. [24] R. C. Carpio, "Otimização no co-processamento de resíduos na indústria do cimento envolvendo custos, qualidade e impacto ambiental", Tese Dr., Instituto de Engenharia Mecânica, Universidade Federal de Itajubá, Itajubá, MG (2005).

[25] Petroleum pitch, "IUPAC Compendium of Chemical Terminology - the Gold Book (1995)", disponivel em <http:// goldbook.iupac.org/P04523.html>, acesso em 16/01/2010.

[26] Sobre o coque, Grupo Unimetal, disponivel em: $<\mathrm{http} / /$ www.grupounimetal.com.br/index.php? option=com_co ntent\&view $=$ article \&id $=57 \&$ Itemid $=131>, \quad$ acesso $\quad$ em $15 / 01 / 2010$.

[27] Coal-derived pitch coke, "IUPAC Compendium of Chemical Terminology - the Gold Book (1995)", disponivel 
em <http://old.iupac.org/goldbook/C01118.pdf>, acesso em 11/01/2010.

[28] A. Gardziella, L. A. Pilato, A. Knop, "Phenolic Resins: Chemistry, Applications, Standardization, Safety and Ecology", $2^{\text {nd }} E d$, Springer, Alemanha (2000).

[29] E. V. Krivokorytov, A. G. Gur'ev, B. I. Polyak, Highcarbon binders in refractories and corrosion-resistant ceramics technology (a review), Glass and Ceramics 55, 5-6 (1998) 144-147.

[30] P. H. R. B. Lemon, Phenol formaldehyde polymers for bonding of refractories, Brit. Ceram. Trans. J. 84, 2 (1985) 53-56.

[31] C. G. Aneziris, J. Hubálková, R. Barabás, Microstructure evaluation of $\mathrm{MgO}-\mathrm{C}$ refractories with $\mathrm{TiO}_{2}$ and $\mathrm{Al}$ additions, J. Eur. Ceram. Soc. 27, 1 (2007) 73-78.

[32] M. Hampel, G. C. Aneziris, Carbon-bonded refractories - characterization of interaction between binder and graphite, Proc. $49^{\text {th }}$ Int. Coll. Refractories, Ed. Verlag Stahleisen, Aachen, Alemanha (2006) 21-25.

[33] L. V. Dolmatov, I. E. Kutukov, G. S. Serkovskaya, Petroleum binders and impregnating materials - substitutes for highly toxic coal products, Chem. Tech. Fuels Oils 38, 2 (2002) 135-137.

[34] G. Buchebner, L. Sampayo, V. Samm, Development, production and application of pitchbonded magnesiacarbon bricks with respect to their improved environmental compatibility, Proc. $47^{\text {th }}$ Int. Coll. Refractories, Ed. Verlag Stahleisen, Aachen, Alemanha (2004) 42-45.

[35] W. Boenigk, J. Stiegert, C. Jacob, D. Schnitzler, C. G. Aneziris, D. Borzov, et al, MgO-C-bricks produced in a cold-mixing process using graphitic binder system, Proc. $47^{\text {th }}$ Int. Coll. Refractories, Ed. Verlag Stahleisen, Aachen, Alemanha (2004) 46-51.

[36] C. G. Aneziris, U. Klippel, Thermal shock behaviour of carbon bonded $\mathrm{MgO}-\mathrm{C}$ refractories with inorganic microand/or nano-additions, Proc. $5^{\text {th }}$ Eur. Oxygen Steelmaking Conf., Ed. Verlag Stahleisen, Aachen, Alemanha (2006) 581-586.

[37] K. P. Singh, G. R. Palmese, Enhancement of phenolic polymer properties by use of ethylene glycol as a diluent, $\mathrm{J}$. Appl. Polym. Sci. 91, 5 (2004) 3096-3106.

[38] V. Wiesche, A. Gardziella, R. Solozabal, J. Suren, Synthetic resins as carbon forming agents for various refractories (carbon yields, analytical methods, structures and emissions), Proc. Unified Int. Technical Conf. Refractories (UNITECR), Ed. Reprints, Aachen, Alemanha (1991) 260-264.

[39] C. S. Bitencourt, V. C. Pandolfelli, Resinas termofixas e a produção de refratários contendo carbono, Cerâmica 59, 349 (213) 1-26.

[40] M. Chanda, S. K. Roy, "Industrial polymers, specialty polymers, and their applications", $1^{\text {st }}$ Ed., CRC, Boca Raton, EUA (2008).

[41] L. Costa, L. Rossi Di Montelera, G. Camino, E. D. Weil, E. M. Pearce, Structure-charring relationship in phenol-formaldehyde type resins, Polym. Degrad. Stab. 56, 1 (1997) 23-35.
[42] "Manual de Produtos Químicos", Companhia Ambiental do Estado de São Paulo - CETESB (2001), disponivel em <http://www.cetesb.sp.gov.br/Emergencia/ produtos/produto_consulta.asp>, acesso em 4/01/2010.

[43] C. Pagliosa Neto, L. J. Gauckler, "Rheological investigations of phenolic resin interactions with refractory raw materials", Tese Pós-Dr., Swiss Federal Institute of Technology (ETH), Zurich, Suíça (2004).

[44] K. Lenghaus, G. G. H. Qiao, D. H. Solomon, 3,5-Dimethylphenol resole resins: Their structure and mechanism of thermal decomposition leading to graphitisation, Polymer 42, 18 (2001) 7523-7529.

[45] K. Lenghaus, G. GuangHua Qiao, D. H. Solomon, C. Gomez, F. Rodriguez-Reinoso, A. Sepulveda-Escribano, Controlling carbon microporosity: The structure of carbons obtained from different phenolic resin precursors, Carbon 40, 5 (2002) 743-749.

[46] A. Gardziella, J. Suren, M. Belsue, Carbon from phenolic resins: carbon yield and volatile components recent studies, Interceram 41, 7-8 (1992) 461-467.

[47] A. Oya, S. Otani, Catalytic graphitization of carbons by various metals, Carbon 17, 2 (1979) 131-137.

48 . Oya, H. Marsh, Phenomena of catalytic graphitization, J. Mat. Sci. 17, 2 (1982) 309-322.

[49] P. Bartha, H. Jansen, H. G. Daldrup, "Carbonaceous refractory shaped body with improved oxidation behavior and batch composition and method for producing the same", US Patent 6846766 B1, 25 Janeiro 2005.

[50] H. Jansen, "Bonding of MgO-C bricks by catalytically activated resin", Millennium Steel Int. (2007) 95-98.

[51] A. P. Luz, V. C. Pandolfelli, Artigo revisão: atuação dos antioxidantes em refratários contendo carbono, Cerâmica 53, 328 (2007) 334-344.

[52] Y. W. Li, C. G. Aneziris, X. X. Yi, S. L. Jin, N. Li, "Formation of dumbbell-shaped $\mathrm{B}-\mathrm{SiC}$ whiskers for the manufacturing of advanced composite refractories in the system $\mathrm{Al}_{2} \mathrm{O}_{3}-\mathrm{ZrO}_{2}-\mathrm{C}$ ", Refractory Manual - Interceram, Ed. DVS-Verlag GmbH, Alemanha (2005) 20-23.

[53] "SILAR ${ }^{\circledR}$ Silicon Carbide Whiskers, Advanced Composite Materials (2009)", disponivel em <http://www. acm-usa.com/whiskers.html>, acesso em 10/01/2010.

[54] S. Bai, H. Cheng, G. Su, Y. Wei, Z. Shen, B. Zhou, Microstructure of dumbbell-shaped biomimetic SiC whiskers, Chin. J. Mater. Res. 14, 5 (2000) 469-474.

[55] C. G. Aneziris, U. Klippel, W. Schärfl, V. Stein, Y. Li, Functional refractory material design for advanced thermal shock performance due to titania additions, Int. J. Appl. Ceram.Tech. 4, 6 (2007) 481-489.

[56] C. G. Aneziris, J. Hubalkova, "Fireproof molded articles or materials and method for the production thereof". US Patent 2008/0280152 A1, 13 Novembro 2008.

[57] M. N. Rahaman, "Ceramic Processing and Sintering", $2^{\text {nd }}$ Ed., Marcel Dekker, Nova York. EUA (2003).

[58] E. M. Petrie, "Titanate and Zirconate Coupling Agents, SpecialChem (2004)", disponivel em $<$ http://www. specialchem4adhesives.com/resources/articles/article. aspx ?id=990 $>$. acesso em 12/11/2009. 
[59] R. Rothon, Bridging the gap with coupling agents, Plastics Additives \& Compounding 5, 3 (2003) 40-45.

[60] K. Weissenbach, H. Mack, "Silane coupling agents", in M. Xanthos, "Functional fillers for plastics", $1^{\text {st }}$ Ed., WileyVCH Verlag GmbH \& Co. KGaA, Weinheim, Alemanha (2005) 63-90.

[61] J. M. Salvatore, "Titanate coupling agents", in M. Xanthos, "Functional fillers for plastics", $1^{\text {st }}$ Ed., WileyVCH Verlag GmbH \& Co. KGaA, Weinheim, Alemanha (2005) 91-114.

[62] "Selection Guide Famasil Silane Coupling Agents", Famas Technology, disponivel em <http://www. famastechnology.com/pdf/Famasil_Coupling_Agents.pdf $>$, acesso em 10/11/2009.

[63] J. H. MacMillan, "Using silanes as adhesion promoters", Computational Chemistry List, disponivel em <www.ccl. net/cca/documents/MacMillan_Papers/adhesion.pdf $>$, acesso em 28/11/2009.

[64] "Silane Coupling Agent Guide, UCT", disponivel em: $<$ http://www.unitedchem.com/>. acesso em 14/11/2009.

[65] Y. Murakami, M. Nemoto, S. Okuzumi, S. Masuda, M. Nagao, N. Hozumi, Y. Sekiguchi, Y. Murata, DC conduction and electrical breakdown of MgO/LDPE nanocomposite, IEEE Trans. Dielec. Elec. Insul. 15, 1 (2008) 33-39.
[66] Y. Murata, Y. Sekiguchi, Y. Inoue, M. Kanaoka, Investigation of electrical phenomena of inorganic-filler/ LDPE nanocomposite material, Proc. Int. Symp. Electrical Insulating Materials, Kitakyushu, Japão (2005) 650-653.

[67] K. P. Murali, S. Rajesh, O. Prakash, A.R. Kulkarni, R. Ratheesh, Comparison of alumina and magnesia filled PTFE composites for microwave substrate applications, Mater. Chem. Phys. 113, 1 (2009) 290-295.

[68] X. Zhao, L. Ye, Study on the thermal conductive polyoxymethylene/graphite composites, J. Appl. Polym. Sci. 111, 2 (2009) 759-767.

[69] Q. Wang, J. Gao, R. Wang, Z. Hua, Mechanical and rheological properties of HDPE/graphite composite with enhanced thermal conductivity, Polym. Comp. 22, 1 (2001) 97-103.

[70] T. Wang, P. M. A. Sherwood, X-ray photoelectron spectroscopic studies of carbon fiber surfaces. 20. Interfacial interactions between phenolic resin and electrochemically oxidized carbon fibers using titanium alkoxide coupling agents and their effect on oxidation behavior, Chem. Mater. 7, 5 (1995) 1031-1040.

(Rec. 02/08/2010, Rev. 17/09/2010, Ac. 16/10/2010) 